\title{
Cetaceans Value and Conservation in the Mediterranean Sea
}

\section{Pace DS ${ }^{1,2^{\star}}$, Tizzi $\mathbf{R}^{1}$ and Mussi $\mathbf{B}^{1}$}

${ }^{1}$ Oceanomare Delphis Onlus, Via Gino Marinuzzi, Rome, Italy

${ }^{2}$ Department of Environmental Biology, Sapienza University of Rome, Viale dell'Università Rome, Italy

*Corresponding author: Daniela Silvia Pace, Oceanomare Delphis Onlus, Via Gino Marinuzzi, Rome, Italy, Tel/Fax +39 06 50910791; E-mail: danielasilvia@oceanomaredelphis.org

Received date: Oct 09, 2015; Accepted date: Oct 13, 2015; Published date: Oct 21, 2015

Copyright: (C) 2015, Pace DS, et al. This is an open-access article distributed under the terms of the Creative Commons Attribution License, which permits unrestricted use, distribution, and reproduction in any medium, provided the original author and source are credited.

\section{Abstract}

This review provides an overview of the Mediterranean diversity and conservation status of cetaceans, and the value associated with their conservation and non-consumptive use. Mediterranean Sea is one of the world's diversity hotspots. Its biodiversity is increasingly under threat in the whole region and key species as cetaceans challenge for conservation.

All the identified threats are interlinked and cumulatively contribute to the habitat degradation of the entire area as well as reduced health status of the cetaceans that live there.

Whales and dolphins, defined as charismatic megafauna, flag species, apex predators and bio indicators of the marine environment health are demanding social substantial changes.

Needs are for spatial prioritization within a comprehensive framework for regional conservation planning, the acquisition of additional information identifying critical habitats in data-poor areas and for data deficient species, and addressing the challenges of establishing transboundary governance and collaboration in socially, culturally and politically complex conditions.

This paper examines research gaps, questions and issues (population abundance estimates, as well as the biological, ecological, physiological characteristics) surrounding cetacean species in the context of biodiversity conservation and highlights the need of targeted conservation management actions to reduce sources of disturb of key threatening processes in the Mediterranean Sea.

The 'precautionary principle' must be adopted at all levels in attempts to mitigate impacts and thus provides scope for the translation of the principle into operational measures.

As natural entities, cetaceans have their objective intrinsic value, not humanly conferred.

Keywords: Cetaceans; Conservation; Mediterranean sea; Anthropogenic threats; Biodiversity

\section{Introduction}

\section{The mediterranean diversity and the value of cetaceans}

The Mediterranean Sea includes $7 \%$ of the world's marine biodiversity $(>17,000$ catalogued marine species), of which approximately one fifth are considered to be endemic; it is estimated that the list may increase with species that have yet to be discovered [1]. In addition, Mediterranean Sea hosts distinctive biodiversity key geomorphologic structures such as submarine canyons, seamounts, mud volcanoes, deep trenches or other specific features (e.g., marine caves). Therefore, undersea ecosystems are very diverse, marine species are not evenly distributed and some areas are of critical importance for the conservation of these species as they provide unique nursery and feeding sites.

Increased endemism and high species richness, as well as unique geomorphologic features, makes the Mediterranean Sea one of the world's biodiversity hotspots [2]. Biodiversity in the Mediterranean is essential to human populations in its support, provisioning and regulation of marine products and services, including cultural and societal benefits [3]. However, Mediterranean is a complex region where ecological and human influences meet and strongly interact, posing a large and growing potential impact to marine biodiversity. Its marine areas, in fact, are amongst the most impacted ecoregions globally [4,5], due to increasing levels of human threats that affect all levels of biodiversity $[1,6,7]$, severe impacts from climate change [2], and biological invasions $[8,9]$.

Cetaceans-whales, dolphins and porpoises-are marine mammals that represent an essential component of marine biodiversity. They have a key ecological role [10] as apex predators in food web in marine and other aquatic ecosystems $[11,12]$, helping to maintain health and integrity as well as to prevent weakens and damages to the systems they are part of. Additionally, some cetaceans are reported as sentinel or indicator for the state of marine ecosystems (e.g., effects of climate change), as well as umbrella species, which have special conservation importance [1,13-17]. 
Cetaceans are also high profile, iconic and charismatic flagship taxa that capture public and media attention as well as political interest [18-19]. They have a wide range of socio-economic, recreational and cultural values, endorsing the view that species and ecosystems intrinsically possess a value (e.g., for their complexity, diversity, spiritual significance, wildness, beauty, or wondrousness) [20]. The idea that nature and biotic diversity have non-instrumental value, value as an end, or value in themselves as well (i.e. 'intrinsic value') [21] has been recognized in some significant international declarations regarding the environment and its protection $[22,23]$.

Historically, cetaceans were culturally and economically important even in the Mediterranean for their by-products: oil, bone, teeth and meat. Today, awareness and appreciation because of their existence or contribution to healthy ecosystems or to society is growing fast. For example, their economic value can be seen in the global boom in whale and dolphin watching ecotourism. Whale and dolphin watching is one of the world's growing tourism sectors and is the main contributor to the income and employment of several coastal communities [24]. The whale-watching industry is worth over a billion dollars a year [25] and the total number of people in high-income countries who have experienced whale watching may now be 100 million, and growing at a rate of 10 million per year.

The biodiversity of the Mediterranean is undergoing important and frequently deleterious changes partially driven by anthropogenic factors in addition to natural forces, and a special effort is needed to better understand how the new biodiversity patterns will affect the Mediterranean food webs and the provision of ecosystem services, as well as ecosystem functioning $[9,26]$. Currently, only $4 \%$ of the Mediterranean (less than 1\% if we exclude the Pelagos Sanctuary for Mediterranean marine mammals, a vast MPA extending over 87,500

\begin{tabular}{|c|c|c|c|c|}
\hline \multirow{2}{*}{ Common name } & \multirow{2}{*}{ Scientific name } & \multirow{2}{*}{ Mainly found in } & \multicolumn{2}{|l|}{ IUCN Red List } \\
\hline & & & Mediterranean Status & Global status \\
\hline Common Bottlenose Dolphin & $\begin{array}{l}\text { Tursiops truncatus } \\
\text { (Montagu, 1821) }\end{array}$ & $\begin{array}{l}\text { everywere in the } \\
\text { Mediterranean }\end{array}$ & Vulnerable & Least concern \\
\hline Striped Dolphin & $\begin{array}{l}\text { Stenella coeruleoalba } \\
\text { (Meyen, 1833) }\end{array}$ & $\begin{array}{l}\text { everywere in the } \\
\text { Mediterranean }\end{array}$ & Vulnerable & Least concern \\
\hline Short-beaked Common Dolphin & $\begin{array}{l}\text { Delphinus delphis } \\
\text { (Linnaeus, 1758) }\end{array}$ & $\begin{array}{l}\text { everywere in the } \\
\text { Mediterranean }\end{array}$ & Endangered & Least concern \\
\hline Risso's Dolphin & $\begin{array}{l}\text { Grampus griseus } \\
\text { (G. Cuvier, 1812) }\end{array}$ & $\begin{array}{l}\text { everywere in the } \\
\text { Mediterranean }\end{array}$ & Data Deficient & Least concern \\
\hline Rough-toothed Dolphin* & $\begin{array}{l}\text { Steno bredanensis } \\
\text { (G. Cuvier in Lesson, 1828) }\end{array}$ & Levantine Sea & Not assessed & Least concern \\
\hline Long-finned Pilot Whale & $\begin{array}{l}\text { Globicephala melas } \\
\text { (Traill, 1809) }\end{array}$ & $\begin{array}{l}\text { everywere in the } \\
\text { Mediterranean }\end{array}$ & Data Deficient & Data Deficient \\
\hline Cuvier's Beaked Whale & $\begin{array}{l}\text { Ziphius cavirostris } \\
\text { G. Cuvier, } 1823\end{array}$ & $\begin{array}{l}\text { everywere in the } \\
\text { Mediterranean }\end{array}$ & Data Deficient & Least concern \\
\hline Killer Whale ${ }^{* *}$ & $\begin{array}{l}\text { Orcinus orca } \\
\text { (Linnaeus, 1758) }\end{array}$ & Strait of Gibraltar & Critically Endangered & Data Deficient \\
\hline Sperm Whale & $\begin{array}{l}\text { Physeter macrocephalus } \\
\text { (Linnaeus, 1758) }\end{array}$ & $\begin{array}{l}\text { everywere in the } \\
\text { Mediterranean }\end{array}$ & Endangered & Vulnerable \\
\hline Fin Whale & Balaenoptera physalus & $\begin{array}{l}\text { everywere in the } \\
\text { Mediterranean }\end{array}$ & Vulnerable & Endangered \\
\hline
\end{tabular}

$\mathrm{km} 2$ of sea surface located in the waters of the Northern Tyrrhenian, Ligurian and Corsica Seas) is in Marine Protected and Managed areas and $75 \%$ of them are located along the basin's North-Western shore. Although these areas included regions with high species diversity, high percentage of endemic species and of threatened/vulnerable species (following the IUCN classification) including cetaceans, they do not cover enough percentage of phylogenetic and functional diversity, which have also an important role in the conservation of marine species and ecosystems [26].

\section{The diversity and conservation status of mediterranean cetaceans}

To date, 21 different cetacean species have been recorded in the Mediterranean Sea [27-29], none of these is endemic. Ten (Table 1) have resident population and regularly occur in the region (common bottlenose dolphin Tursiops truncatus, striped dolphin Stenella coeruleoalba, short beaked common dolphin Delphinus delphis, Risso's dolphin Grampus griseus, rough-toothed dolphin Steno bredanensis, pilot whale Globicephala melas, Cuvier's beaked whale Ziphius cavirostris, killer whale Orcinus orca, sperm whale Physeter macrocephalus, and fin whale Balaenoptera physalus). Three other species (Table 2) are considered visitors (false killer whale Pseudorca crassidens, common minke whale Balaenoptera acutorostrata, humpback whale Megaptera novaeangliae), seven (Table 3) are vagrant (dwarf sperm whale Kogia sima, northern bottlenose whale Hyperoodon ampullatus, Blainville's beaked whale Mesoplodon densirostris, Gervais' beaked whale Mesoplodon europaeus, sei whale Balaenoptera borealis, north Atlantic right whale Eubalaena glacialis, grey whale Eschrichtius robustus) and one (Indo Pacific humpback dolphin Sousa chinensis) is alien (Table 4). 
Page 3 of 24

$$
\text { (Linnaeus, 1758) }
$$

Table 1: List of cetacean species represented by population resident in the Mediterranean Sea. ${ }^{*}$ Rough-toothed dolphin was formerly considered a visitor to the Mediterranean Sea, but now a resident population has been recognized in the Levantine Basin due to frequent sightings and strandings in this area. ${ }^{*}$ Although other authors considered the killer whale as a visitor, we prefer the classification of resident, since there is a small population of about 30 individuals inhabiting the Gibraltar Strait.

\begin{tabular}{|l|l|l|l|l|}
\hline Common name & Scientific name & Where occurred & \multicolumn{2}{l|}{ IUCN Red List } \\
\cline { 2 - 5 } False Killer Whale & $\begin{array}{l}\text { Pseudorca crassidens } \\
\text { (Owen, 1846) }\end{array}$ & $\begin{array}{l}\text { Spain, France, Italy, Malta, Croatia, Greece, } \\
\text { Turkey, Egypt, Syria, Israel }\end{array}$ & Not assessed & Global status \\
\hline Common Minke Whale & $\begin{array}{l}\text { Balaenoptera acutorostrata } \\
\text { (Lacépède, 1804) }\end{array}$ & $\begin{array}{l}\text { Spain, Morocco, France, Italy, Tunisia, Greece, } \\
\text { Israel }\end{array}$ & Not assessed & Data Deficient \\
\hline Humpback Whale & $\begin{array}{l}\text { Megaptera novaeangliae } \\
\text { (Borowski, 1781) }\end{array}$ & $\begin{array}{l}\text { Spain, France, Italy, Tunisia, Slovenia, Greece, } \\
\text { Syria }\end{array}$ & Not assessed & Least concern \\
\hline
\end{tabular}

Table 2: List of cetacean species identified as visitors in the Mediterranean Sea.

\begin{tabular}{|c|c|c|c|c|}
\hline \multirow[b]{2}{*}{ Common name } & \multirow{2}{*}{ Scientific name } & \multirow{2}{*}{$\begin{array}{l}\text { Where } \\
\text { occurred }\end{array}$} & \multicolumn{2}{|c|}{ IUCN Red List } \\
\hline & & & $\begin{array}{l}\text { Mediterrane } \\
\text { an Status }\end{array}$ & $\begin{array}{l}\text { Global } \\
\text { status }\end{array}$ \\
\hline Sei Whale & $\begin{array}{l}\text { Balaenoptera } \\
\text { borealis } \\
\text { (Lesson, 1828) }\end{array}$ & $\begin{array}{l}\text { Spain, } \\
\text { France }\end{array}$ & $\begin{array}{l}\text { Not } \\
\text { assessed }\end{array}$ & $\begin{array}{l}\text { Endanger } \\
\text { ed }\end{array}$ \\
\hline \multirow{2}{*}{$\begin{array}{l}\text { North Atlantic Right } \\
\text { Whale }\end{array}$} & $\begin{array}{l}\text { Eubalaena } \\
\text { glacialis }\end{array}$ & \multirow{2}{*}{$\begin{array}{l}\text { Algeria, } \\
\text { Italy }\end{array}$} & \multirow{2}{*}{$\begin{array}{l}\text { Not } \\
\text { assessed }\end{array}$} & \multirow{2}{*}{$\begin{array}{l}\text { Endange } \\
\text { ed }\end{array}$} \\
\hline & $\begin{array}{l}\text { (P.L.S. Müller, } \\
\text { 1776) }\end{array}$ & & & \\
\hline Grey Whale & $\begin{array}{l}\text { Eschrichtius } \\
\text { robustus } \\
\text { (Lilljeborg, 1861) }\end{array}$ & $\begin{array}{l}\text { Israel, } \\
\text { Spain }\end{array}$ & $\begin{array}{l}\text { Not } \\
\text { assessed }\end{array}$ & $\begin{array}{l}\text { Least } \\
\text { concern }\end{array}$ \\
\hline Dwarf Sperm Whale & $\begin{array}{l}\text { Kogia sima } \\
\text { (Owen, 1866) }\end{array}$ & Italy & $\begin{array}{l}\text { Not } \\
\text { assessed }\end{array}$ & $\begin{array}{l}\text { Least } \\
\text { concern }\end{array}$ \\
\hline $\begin{array}{l}\text { Northern Bottlenose } \\
\text { Whale }\end{array}$ & $\begin{array}{l}\text { Hyperoodon } \\
\text { ampullatus } \\
\text { (Forster, 1770) }\end{array}$ & $\begin{array}{l}\text { Spain, } \\
\text { France }\end{array}$ & $\begin{array}{l}\text { Not } \\
\text { assessed }\end{array}$ & $\begin{array}{l}\text { Data } \\
\text { Deficient }\end{array}$ \\
\hline $\begin{array}{l}\text { Blainville's Beaked } \\
\text { Whale }\end{array}$ & $\begin{array}{l}\text { Mesoplodon } \\
\text { densirostris } \\
\text { (Blainville, 1817) }\end{array}$ & Spain & $\begin{array}{l}\text { Not } \\
\text { assessed }\end{array}$ & $\begin{array}{l}\text { Data } \\
\text { Deficient }\end{array}$ \\
\hline $\begin{array}{l}\text { Gervais' Beaked } \\
\text { Whale }\end{array}$ & $\begin{array}{l}\text { Mesoplodon } \\
\text { europaeus } \\
\text { (Gervais, 1855) }\end{array}$ & Italy & $\begin{array}{l}\text { Not } \\
\text { assessed }\end{array}$ & $\begin{array}{l}\text { Data } \\
\text { Deficient }\end{array}$ \\
\hline
\end{tabular}

Table 3: List of cetacean species considered as vagrant in the Mediterranean Sea.

Cetacean distribution varies according to the physical, chemical, and biological characteristics of the water masses they use [30]. The effects of oceanographic phenomena and wind-induced movements (e.g., water currents, local divergence, upwelling areas and water fronts, and thermocline depth), the topography as well as human activities affect and influence the presence of cetaceans and can be used to characterize their distribution.

\begin{tabular}{|c|c|c|c|c|}
\hline \multirow[b]{2}{*}{ Common name } & \multirow{2}{*}{$\begin{array}{l}\text { Scientific } \\
\text { name }\end{array}$} & \multirow{2}{*}{$\begin{array}{l}\text { Where } \\
\text { occurr } \\
\text { ed }\end{array}$} & \multicolumn{2}{|l|}{ IUCN Red List } \\
\hline & & & $\begin{array}{l}\text { Mediterranea } \\
\text { n Status }\end{array}$ & $\begin{array}{l}\text { Global } \\
\text { status }\end{array}$ \\
\hline $\begin{array}{l}\text { Indo-Pacific humpback } \\
\text { dolphin }\end{array}$ & $\begin{array}{l}\text { Sousa } \\
\text { chinensis } \\
\text { (Osbeck, } \\
1765)\end{array}$ & Israel & Not assessed & $\begin{array}{l}\text { Near } \\
\text { threatene } \\
\text { d }\end{array}$ \\
\hline
\end{tabular}

Table 4: List of cetacean species considered as alien in the Mediterranean Sea.

In marine environments, distribution can be generally described as coastal (in near shore waters), neritic (in waters on the continental shelf/slope), or oceanic (in waters beyond the continental slope, in the open seas or oceans). The ten cetacean species resident in the Mediterranean Sea can therefore be subdivided in three main categories depending from their habitat preferences: coastal, slope and pelagic species. Examples of cetaceans that reside primarily in coastal waters are populations of common bottlenose dolphins (they can be encountered in bays, estuaries and lagoons too) and short beaked common dolphin (they are often found inshore at depths lesser than $500 \mathrm{~m}$ ). Slope species as Risso's dolphin, pilot whale and sperm whale occur mainly around the shelf edge, where the water depth increases rapidly from $500 \mathrm{~m}$ over the continental shelf to $1500 \mathrm{~m}$. The shelf edge is an important habitat a highly productive areas with nutrient upwellings leading to high densities of phyto and zooplankton and thus fish species. The deep water off the continental shelf provides suitable habitats for pelagic species such as fin whale, striped dolphin, and Cuvier's beaked whale. Rough-toothed dolphin has been observed in both coastal and pelagic waters of a portion of the eastern Mediterranean Sea, while killer whale is distributed in the shallow waters of the Gibraltar Strait only.

Beyond these main habitats, minor morphostructures of particular interest for the marine environment in the Mediterranean as submarine canyons and mountains have recently been reported as hotspots for Mediterranean cetaceans [31,32]. For example, in the submarine canyon of Cuma-off Ischia and Ventotene Islands (central Tyrrhenian Sea)-seven cetacean species have been commonly 
observed [33,34]. The area is also reported as one of the few remaining stable strongholds for the endangered short beaked common dolphin in the Mediterranean [35] and as a significant ground for feeding and social activities for the endangered sperm whale [36,37]. Furthermore, the Genoa canyons in the western Ligurian Sea seem to attract the Cuvier's beaked whales and sperm whales because of the high productivity of deep-sea squid in the area $[38,39]$ and the submarine mountains in the Tyrrhenian Sea seem to influence the distribution of the striped dolphin in the region [40]. Additional studies on cetaceans distribution related to oceanographic conditions were conducted in the Alboran Sea [41], Gulf of Lion [42], Ionian and Aegean Sea [43]. IFAW has run a basin wide acoustic survey mainly focused on sperm whale [44]. However, data on overall distribution of all species are still scarce or absent for the Levantine basin as well as for the central and the southern part of the Mediterranean Sea.

There is evidence for many of the ten resident species may have evolved into distinct subpopulations genetically differentiated from the Atlantic ones. Bottlenose dolphin exhibits population structures that correspond well to the main Mediterranean oceanographic basins $[45,46]$, with evidence for fine scale population division within the Adriatic and the Levantine seas and for distinction between populations inhabiting pelagic and coastal regions [46]. Furthermore, present bottlenose dolphin genetic structure patterns in the Mediterranean Sea seems to largely result from the stochastic distribution of Atlantic genetic diversity during a recent post-glacial expansion and North Atlantic and Mediterranean populations likely constitute a single metapopulation, with pelagic populations acting as genetic source for coastal ones [46]. Genetic studies strongly suggest that the striped dolphin Mediterranean and eastern North Atlantic populations are isolated from each other, with little or no gene flow across the Straits of Gibraltar $[47,48]$. Inside the Mediterranean there is some clinical variation in body size and tissue pollutants levels suggestive of population structure and/or restriction in gene flow between areas $[49,50]$. At a finer spatial scale, there is some evidence of genetic differentiation between inshore and offshore subpopulations in the Ligurian Sea [51]. A significant level of genetic divergence between Mediterranean and Atlantic common dolphin populations was also proved [45] with a possible genetic exchange involving only animals from the Alboran Sea [52]. Based on the available information, Risso's dolphins in the Mediterranean Sea are genetically differentiated from those in the eastern Atlantic, implying that gene flow between the two areas is limited and that the Mediterranean animals constitute a distinct population [51]. Genetic characteristics of animals sampled in the Ligurian-Corso-Provençal basin were variable but suggestive of intra-basin structuring [51]. The Mediterranean population of Cuvier's beaked whale is genetically distinct from neighbouring populations in the eastern North Atlantic and therefore it has been considered an evolutionarily significant unit [53]. Genetic analyses based on both mitochondrial and nuclear DNA indicated differences between the Mediterranean population and fin whales in Atlantic coastal waters of Spain, Canada, Greenland, and Iceland [54] although limited but recurrent gene flow was detected in more recent analysis [55]. Finally, genetic data suggest that sperm whales in the Mediterranean constitute a separate population [56,57]. No genetic analyses between Mediterranean and Atlantic have been reported for other species such as long finned rough toothed dolphins, pilot and killer whale, therefore, nothing is known about possible gene flow through the Strait of Gibraltar.

The conservation status of cetaceans in the Mediterranean Seas is a source of concern. Two populations from the region have been listed as
'Endangered' in the IUCN Red List of Threatened Species: the Mediterranean subpopulation of short beaked common dolphins (Delphinus delphis) in 2003 and the Mediterranean subpopulation of sperm whales (Physeter macrocephalus) in 2012.

The IUCN Red List assesses species in accordance with a set of criteria and arrange them in different classes according to their probability of risk of extinction [29]. All species fall into one of nine categories: Extinct (EX), Extinct in the Wild (EW), Critically Endangered (CR), Endangered (EN), Vulnerable (VU), Near Threatened (NT), Least Concern (LC), Data Deficient (DD) and Not Evaluated (NE) (Figure 1). At least $66.7 \%$ of whale and dolphins are threatened with extinction. One third of species are assessed as Data Deficient, with no sufficient information to categorize them and numbers too low to be counted (in other words, there is insufficient information to determine which Red List Category a species should be placed in). This means that the real number of threatened species could be much higher and some species could be declining or perhaps even disappearing from the Mediterranean without us even noticing.

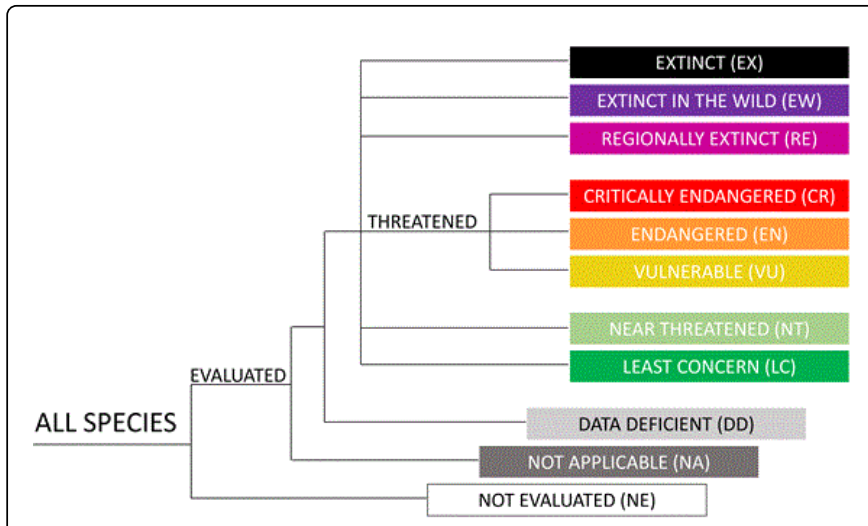

Figure 1: IUCN Red List categories at the regional scale (source: IUCN [29]).

\section{The Human Factor and Threats to Cetaceans in the Mediterranean}

The Mediterranean Sea is economically important, being exploited for fisheries, oil and gas extraction, and offshore renewable energy; it is also used for shipping, tourism and recreation as major uses [58,59]. The region is home to some 507 million human inhabitants, from a wide variety of countries and cultures. The Blue Plan [60] reports that the population of the coastal states of the Mediterranean will rise to between 520 and 570 million in 2025 and to 700 million by the end of the 21 st century. The region also receives a large number of visitors: in 2005, 246 million people visited the Mediterranean [60].

Heavy pressure from visitors and residents in the Mediterranean is causing severe environmental degradation [60,61]. A growing coastal population with associated industry creates pollution. This will include sewage, as well as industrial and incidental discharges of chemicals such as the Persistent Organic Pollutants (POPs). In addition, increased coastal building and dredging for building materials and to keep ship-ways clear may directly degrade marine habitats and, together with the concomitant increases in boat traffic due to population pressures linked to tourism, introducing high levels of noise pollution into the marine environment. 
Urbanization, coastal development, pollution, and unsustainable exploitation of natural resources such as marine fish are just some of the many human activities that are leading to an ever-increasing number of Mediterranean species, including cetaceans, to be facing a high risk of detriment [62]. Cetaceans are wide ranging species found in diverse habitats, from shallow coastal waters to abyssal canyons. Therefore, they encounter a multitude of anthropogenic threats, including incidental by-catch in fishing gear, exposure to pathogens and pollutants, collisions with shipping vessels and underwater noise [63]. However, threats facing cetaceans have changed through time. While overkill from hunting was the most obvious and immediate threat to some species and populations during much of the 20th century, the relative importance of other threats has increased dramatically during the last few decades [64]. It is difficult to distinguish the effects of one threat from those of another when multiple threats are acting simultaneously or synergistically; this is particularly evident in the Mediterranean area where interactions between cetaceans and anthropogenic activities are numerous and diverse. For example, in December 2009, a pod of seven male sperm whales stranded along the coasts of Southern Italy. It appears the cause of death was prolonged starvation not from plastic obstruction (even though plastic was found in all dissected individuals) but due to a lack of prey. High concentrations of pollutants in the tissues of the stranded animals led researchers to conclude that prolonged starvation stimulated the mobilization of highly concentrated lipophilic contaminants from their adipose tissue, which entered the blood circulation and may have impaired immune and nervous functions [65]. Managing such complex interactions is probably the most difficult task in cetacean conservation, but also the most important part of it. Every area is different and the type and extent of interactions between humans and cetaceans vary greatly, even depending on a number of factors such as the natural characteristics of the area, the types of human activities and the species of cetaceans present [66].

The most important causes of threat for Mediterranean cetaceans are related to habitat loss and degradation (including climate alterations), overexploitation (intended as food resource depletion), human disturbance (ranging from unregulated whale watching to ship and boat collisions), entanglement of animals in fishing gear (by catch), the introduction of invasive non-native marine species, and different kind of marine pollution $[29,62,66]$.

Habitat loss and degradation: Resulting from direct or indirect consequence of human activities (e.g., mechanical and chemical pollution, dredging, anchoring, trawling, urbanisation, industrialization, tourism development, climate change and so on), the habitat degradation ultimately affects Mediterranean cetacean populations since poorer habitat quality decreases the value of that available habitat for the animals [66]. This is particularly relevant for coastal areas where any coastal development that changes the coastal marine environment-either directly, for example in construction work or indirectly by otherwise affecting other marine life-may have knockon effects for cetaceans. Whilst those animals that have habitats that include inshore areas may be most vulnerable, inshore areas frequently serve as nursery grounds for fish species and prey may therefore be vulnerable [67].

Climate-related phenomena involving changes in sea level, sea temperature, oceanography and acidification are considered source of habitat alteration. Climate variation may deviate migratory patterns, destroy habitat (particularly in nutrient-rich seas), and drastically change ocean circulation, vertical mixing and overall climate patterns.
There may be changes in nutrient availability, biological productivity, and the structure of marine ecosystems from the bottom of the food chain to the top. Therefore, as with many other taxa, climate change is expected to result in geographic range shifts of cetacean species as they track changes in temperature to remain within their ecological niches. Such changes in geographic range could have implications for the conservation and management of cetaceans.

According to IPCC [68] and Lionello et al. [69], the Mediterranean area is a climate change hotspot, especially vulnerable to the increased sea surface temperature caused by greenhouse gas emissions. Mediterranean sea superficial temperature is significantly warming in the $2000-2100$ period by $0.35^{\circ} \mathrm{C}$ per decade, with a seasonal trend variability peaking in spring, followed by summer, autumn and winter [59]. Changes in sea temperature are likely to result in location and abundance changes to phyto and zooplankton communities with implications for dependent species, such as cetaceans [70-71]. Both small and large cetaceans seems to have the capability to rapidly perform shifts in distribution and abundance patterns strongly associated with adaptive search behaviour in relation to both changing levels of abundance in their prey and elevated sea surface temperatures [72], providing new evidence on high ecological plasticity in response to mutable predator-prey trophic relationships and elevated seasurface temperatures.

Changes in oceanography have been also assessed as of potential concern to Mistycetes through impacts on distribution and migration associated with the availability of suitable habitat and prey (e.g., breeding and feeding). For example, the selection of calving sites may be influenced by factors such as currents and given the possible changes in oceanography, existing calving sites may become smaller in size or rendered unsuitable in the future. Following Simmonds et al. [73], a summary of the effects of climate change on Mediterranean cetaceans is reported in Figure 2.

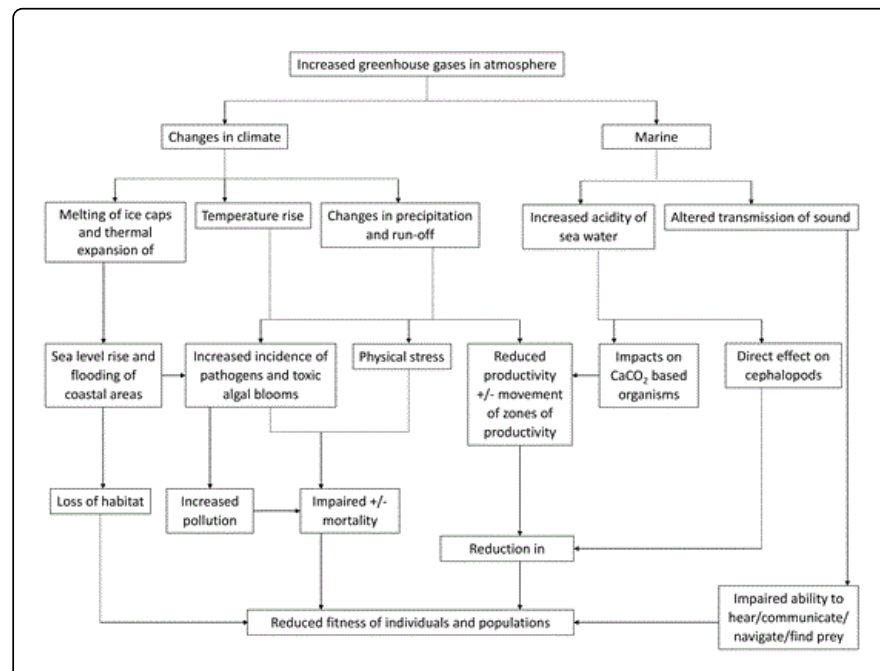

Figure 2: Climate change effects on Mediterranean Cetaceans (source Simmonds et al. [73]).

Driven by increasing levels of atmospheric carbon dioxide and subsequent chemical changes in the sea, acidification is underway and detectible in the Mediterranean waters. Ocean acidification results from the uptake of anthropogenic carbon dioxide $\left(\mathrm{CO}_{2}\right)$ of which around one third is absorbed by the oceans [74] where it reacts with 
water to form carbonic acid $\left(\mathrm{H}_{2} \mathrm{CO}_{3}\right)$ which further dissociates into hydrogen ions $(\mathrm{H}+)$ and carbonate ions $\left(\mathrm{CO}_{32}-\right)$. Increased $\mathrm{H}+$ ions lower the $\mathrm{pH}$ of the water. Since pre-industrial times, acidification has lowered ocean $\mathrm{pH}$ by 0.1 units and climate models predict this trend will continue, with a further $0.2-0.3$ unit decline by 2100 [75]. The phenomenon has been assessed as of potential concern to large cetacean through impacts on prey availability [76].

As Hoffman et al. [77] pointed out, biological implications of climate changes on cetaceans are likely to come through effects on their food supply and reproduction. Species displacement and decreases in survival are of medium certainty, and while there is the potential for significant effects on population, there is insufficient information to predict climate-related population declines.

Interaction with fishery and by-catch: Fisheries can affect cetaceans both directly and indirectly. Effects on the animals may include [78] direct bycatch, injuries or death by fishermen perceiving the animals as competitors, prey depletion or changes in food prey composition/ distribution caused by overfishing, habitat loss and/or degradation (e.g., from bottom trawling), short-to long-term modifications in cetacean behavior leading to emigration, dispersion or reduced reproductive rates as a consequence of direct or indirect interactions with fisheries.

There is a long history of interactions between cetaceans and fisheries in the Mediterranean Sea. Cetaceans were always attracted to fishing gears; they attempt to remove bait and catches during commercial and recreational fisheries. Cetaceans also feed at mariculture (fish farm) enclosures. With some exception, current interactions mainly involve coastal, small-scale artisanal fishery. Gears likely to have the most interaction with cetaceans are trammel and bottom gillnets, driftnets trawls, longlines and purse seines.

Fishing operation concentrate food of interest, decreasing energy expenditure associated with foraging by cetaceans [79]. Nursing females may especially benefit from this feeding technique. Fishing operation may permit cetaceans to select food of higher caloric value. Some feeding niches, not otherwise available to cetaceans, may be opened up, making prey easier to access that might be normally difficult, for example because of depth required to dive [80], while others nurturing niches could be destroyed by the impact of the fisheries operations. Such anthropogenic food patches can affect cetacean populations by causing changes in the spatial use of an area and by altering behavior or social structure and organization [80-82]. Taking advantage from these human "feeding stations" is a learned behavior, with increasing more individual seeking out fishing gear for an easy meal. Acoustic aspects of the fishing activity (e.g., cavitation noise from changes in the propeller speed of ship engines, gear haulers, depth sounders and radio buoys) may act as dinner bell. It has been suggested that this type of feeding behavior is also passed from generation to generation by observation and participation [80].

Interactions between cetaceans and coastal fisheries may negatively affect the fisheries through [83], Abrasion and wounds to fish caused during capture attempts or while "playing" with fish during fishing operation, even when they are satiated. Cetaceans may take portions of fish or the entire fish, rendering them non marketable. Catches' reduction disturbing fishing operation. Cetaceans can causing fish schools to disperse and escape from the net. In the case of fish farms, dolphins may attack and harass fish through the pen walls, thus stressing, scarring and wounding the fish and resulting in lower product quality through reduced value or reduced fish weight. Gears' damaging (gear may not fish as efficiently and a loss of catch may result). Additional costs includes time for repairing fishing gears and expenses for new material. A real or perceived ecological competition with cetaceans, based on the conviction that depredation-particularly by dolphins-reduces the amount of fish available to fisheries.

Information on the economic effects of dolphin interactions with Mediterranean fisheries is qualitative and inadequately documented. Detailed quantitative information on the spatial, seasonal, and operational features of small-scale coastal trammel and gillnet fisheries in the region is missed. Identification of hotspots where overlap occurs (i.e., high dolphin densities matched with high levels of fishing activity) should be followed by rigorous site-specific studies to characterize and quantify the costs of dolphin depredation [83]. Mediterranean dolphins are often thought to compete with fishermen reducing fishery yields [83], but no robust scientific investigation support this hypothesis. On the other hand, [84] showed how competitive effects are more likely to affect dolphins than humans, having the total biomass removed by fishery exceeded that removed by dolphins by a factor of 33 .

A brief description of the different fishing gears and the type of interactions with cetacean species is reported below.

Trammel and bottom gillnets: A trammel net consists of two/three layers of netting with a slack small mesh inner netting between two layers of large mesh netting within which fish will entangle. Target species are demersal species, fish and crustaceans. A set gillnet consists of a single netting wall kept more or less vertical by a float line and a weighted ground line. Gillnets are of special interest for artisanal fisheries because it is a low cost fishery. Target species are pelagic, demersal and benthic species. The size distribution of the catch is very much dependent on the mesh size used in the gillnet. Trammels and gill nets represents the small-scale artisanal fishery, most often familyowned. Typically traditional, involve relatively small fishing boats, making short fishing trips, close to shore, mostly for local consumption.

Interactions with cetaceans involve mainly the common bottlenose dolphins. Although, the lack of adequate data prohibits an assessment of the full extent of the interactions, these have been reported from a number of Mediterranean areas. The feeding behavior of dolphins on the nets it is hard to record. Defining interaction when dolphins are present around a fishing net (within $400 \mathrm{~m}$; [85]), or assuming that activities visible at the surface are representative of activities beneath the surface [86] could lead to a misinterpretation of the real dolphin behavior. Moreover, during the night period visual observations are impossible. Acoustic monitoring could result more effective and seems to lead through a better comprehension of the dolphins' behavior around the nets. Fossa et al. [87], using a passive acoustic device to evaluate cetacean activities and damages observed on the net to quantify depredations, points out that true interactions resulted less numerous than expected, if considering dolphins presence and foraging around the nets.

Researchers, probably stimulated to the widespread fishermen complains, beyond describing the interactions often focused on assessment of economic lost and gears/catches damages [85,86,88]. Overall, direct observations show a modest and seasonal impact on the fishing community. The presumably dolphin-caused net damage may result not only from entanglement with bottom debris, natural substrate or inadequate handling/maintenance of the fishing gear [89], but also from interaction with other predators like logger head sea 
turtles (Caretta caretta), Mediterranean moray Muraena helena, and other species as European otter (Lutra lutra) and tope shark (Galeorhinus galeus). The morphological damage category 'Bite', with its characteristic shape and size, is sometime attributable to the action of other predators cuttlefish (Sepia spp.), common octopus (Octopus vulgaris), European conger (Conger conger) [85].

A study conducted in the MPA of Porto Cesareo, Italy [90], found inconsistency between high reported occurrence of dolphins and depredation events around Porto Cesareo and the results of dedicated surveys in the months of highest reported occurrence, in which any dolphin was detected. Authors underline the possibility that interviews made during the study were perceived as an opportunity to influence decision-making regarding monetary compensations for depredation. Such perception may have introduced a positive bias in the reported damage (i.e. the actual extent of depredation by dolphins could be over-reported).

Although dolphins benefit from depredating fish from gillnets, the association with gillnets can be harmful because it exposes bottlenose dolphins to entanglement risk. Bycatch event were documented in the past [91] and more recently [86]. A couple of studies carried out in the Balearic Islands suggest that the use of pingers (i.e., acoustic deterrent devices) could be an effective way to reduce bottlenose dolphin interactions $[92,89]$. However, the possible negative effects on dolphins and the habitat should be assessed, the use of the deterrent devices may be inconsistent with the preservation of the habitats and biodiversity.

Driftnets: This fishing gear consists of panels of nets equipped with floating devices on the top edge and a leaded rope to maintain them in a vertical position without compromising their properties [93]. The characteristics of the nets, such as colour, mesh size, length or height may vary depending on the target species or the home ports from which the vessels operate. In swordfish and tuna fisheries, driftnets are deployed at the sunset in a " $\mathrm{S}$ " or zig-zag pattern at dusk and are hauled in with the help of a winch before daybreak [94]. In the Mediterranean, driftnets target a variety of pelagic species including European anchovies (Engraulis encrasicholus), sardines (Sardina pilchardus), small tunas such as Atlantic bonitos (Sarda sarda), bullet tuna (Auxis spp) or specifically swordfish (Xiphias gladius) or albacore (Thunnus alalunga).

Driftnets, ostensibly banned from the Mediterranean by both the European Union and the International Commission for the Conservation of Atlantic Tuna (ICCAT) since 2002 and 2003, respectively, continue to be used illegally across the region to catch valuable large pelagic species, mainly swordfish and tuna. There are estimated to be up to 600 illegal driftnet vessels operating in the Mediterranean, including many from EU Member States, namely Italy (100+vessels), and France (70-100 vessels). Major fleets are also based in Morocco (150-300 vessels), Turkey (up to 110 vessels) and Algeria [95].

Driftnets are responsible for the largest proportion of cetacean bycatch in the Mediterranean and it is estimated that these nets cause the deaths of 100.000 cetaceans annually [78]. Trapped in the nets, the cetaceans die because they cannot rise to the surface to breathe. The species caught include almost all of those found in the Mediterranean, including fin whales, sperm whales, long finned pilot whales, Cuvier's beaked whales, Risso's dolphins, bottlenose dolphins, striped dolphins and short beaked common dolphins [91,96]. Bycatch involved also various species of elasmobranches, pelagic rays, turtles and seabirds.
Of the large cetaceans, the sperm whale is the most affected by this method of fishing $[94,97]$. Even if most bycatch of cetaceans results in death, there are limited positive circumstances where live release is accomplished. For example, as documented by Pace et al. [98], a group of five sperm whales, found completely entangled in a driftnet 40 miles southwest off Capo Palinuro (Southern Tyrrhenian Sea, Italy), was freed by the Italian Coast Guard scuba-diving team during a two-day rescue operation.

Trawlers: Trawl nets are towed nets consisting of a cone-shaped net with a sac at the end for collecting the target species. To take various species of fishes, squids and crustaceans, trawls can operate at the bottom, in midwater, or at surface. Bottom trawlers represent the main fleet in the Mediterranean and the main target of cetacean exploitation. In the Mediterranean, interactions between trawlers and several cetacean species reportedly occur, the main species involved being the common bottlenose dolphin [82,88-100]. Individuals exploit food concentrated by trawling operations. Dolphins have learned to follow vessels to take advantage of organisms, stirred up and attracted by the net or discarded/fallen from the net after hauling. Apart from few bycatch incidents, the main impact of trawl fisheries on Mediterranean cetaceans, particularly on coastal species feeding on demersal prey such as the bottlenose dolphin, may be due to direct or indirect foodweb interactions and habitat loss [78].

Longlines: This gear consists in a long line, called the main line, with baited hooks (bait can be natural or artificial) attached at intervals by means of branch lines called snoods. A snood is a short length of line, attached to the main line using a clip or swivel, with the hook at the other end. Longlines can be placed at the surface or at the bottom; they can be anchored, or left to drift. Hook and line units may be used singly or in large numbers up to thousands. Targets are pelagic, demersal and benthic species; the use of different hook sizes and fishing depths allows fishermen considerable flexibility in their choice of target species. Longlines are commonly used in the Mediterranean for catching large pelagic species such as swordfish (Xiphias gladius), bluefin tuna (Thunnus thynnus), and albacore (Thunnus alalunga).

Most cetacean-longline interactions are thought to be the result of odontocetes being attracted to the fishing gear or boat because of opportunities to remove bait or caught fish; this may occasionally also result in entanglement or hooking, injury and mortality of the cetaceans. Depredation is usually identified when hauls reveal fish damaged in a particular way (e.g., Lauriano et al. [85]). Fish damaged by cetaceans is usually distinguishable from shark-damaged fish with the latter typically being bitten in half with clean bites or multiple smaller bites [101]. Flesh may be torn from hooked fishes or fish maybe removed completely (leaving only the head or lips) Depredation on longline gear is believed to most frequently occur during gear hauling (e.g., Wang and Yang, [102]) but can also occur during the setting and soak of the line.

Although a few cases of incidental catches of cetaceans have been reported, clear evidence is often missing because cetaceans can be released alive at sea by fishermen. Bycatch in these fisheries affect striped dolphin, common bottlenose dolphin, false killer whale, Risso's dolphin, short beaked common dolphins, long finned pilot whales and sperm whale [103-108].

Mussi et al. [106] reported interactions with fisheries using illuminated handlines for squids. These involved small groups of striped dolphins, Risso's dolphins, long finned pilot whales and sperm whale waiting near the fishing boats until the light had attracted a great 
number of squids. Cetaceans would then take profit of the higher prey density and forage near the fishing boats. However, no cetacean bycatch was reported during these interactions.

Purse seine: A purse seine is made of a long wall of netting framed with floatline and leadline (usually, of equal or longer length than the former) and having purse rings hanging from the lower edge of the gear, through which runs a purse line made from steel wire or rope which allow the pursing of the net. Purse seines can reach more than $2000 \mathrm{~m}$ in length and $200 \mathrm{~m}$ in depth, varying in size according to the vessel, mesh size, and target species. For most of the situation, it is the most efficient gear for catching large and small pelagic species that is shoaling, from tuna to anchovies and sardines. Bycatch in purse seine fisheries, particularly in the eastern tropical Pacific Ocean, has been the focus of intense monitoring for the past few decades. With the realization in the 1980's that the purse seine fishery that set on tunadolphin associations resulted in substantial dolphin mortality, new fishing techniques were developed to mitigate that mortality. The use of these techniques became mandatory for the vessels that exploited tuna-dolphin associations, and a very ambitious observer program was implemented to document exhaustively the fishing operations by all large purse seiners in the region. A bottom-up approach where fishers play a role in finding practical solutions that are economically viable has been the best approach to mitigating bycatch [109].

In the Mediterranean Sea, the industrial purse seine fleet is represented by the "tonnare volanti" where pelagic fish concentrations are detected by airplanes sightings and huge vessels set surroundings nets. Following the increasing demand from the market for highly prized sushi and sashimi, Japanese introduced this fishery in the early 1980's. Around Malta Island, between 2000 and 2002, the tuna purse seine fishery (using eight airplanes for fish aggregation detection) went up from 6-7 to 30 vessels [110]. In Italian waters, the major fleet is concentrated in the southern Tyrrhenian Sea, with other vessels in the Adriatic Sea, in the Ligurian Sea and in the Sicily channel [111].

The highest proportion of the total world catch of bluefin tuna is from the Mediterranean Sea. The increasingly larger purse seine catches and the development of a large, new, technologically advanced fishing fleet, together with the misreporting of catches in order to comply with the Total Allowable Catch (TAC) for this species (established in 1998), make it difficult to carry out reliable stock evaluations. The expansion of bluefin tuna farming in the Mediterranean Sea since 1997 [112], where wild specimens are transferred live for fattening (tuna ranching), has further contributed to this misreporting. The current stock is approximately $1 / 3$ of that estimated in the early seventies, and if pressure persists, it is likely to lead to the collapse of the fishery [113].

Rare and old reports exist of cetacean bycaught in tuna purse-seine in the Mediterranean (e.g., Magnaghi and Podestà [114]). Overall, the impact of these nets on Mediterranean cetaceans was considered to be negligible [91]. However, reliable information is completely lacking, and thus an accurate assessment of the impact of tuna purse seine fishing on cetaceans in the Mediterranean is presently impossible. Interactions with small purse seines using light attractions targeting pelagic schooling fishes were recorded for Risso's dolphin and striped dolphin [33]. Both species profiting of fishing aggregation attracted from the lights and hunting preys out and within the net.

Mariculture: Mariculture is the farming of aquatic organisms in salt water. Major categories of mariculture species are seaweeds, molluscs, crustaceans, and finfish. According to the latest information, FAO estimates that world food fish aquaculture production rose by 5.8 percent to 70.5 million tonnes in 2013, with production of farmed aquatic plants (including mostly seaweeds) being estimated at 26.1 million tonnes [115].

During the last years in Mediterranean waters, the opportunistic feeding behaviour of bottlenose dolphin was frequently recorded close to the fish farms $[82,99,116]$. Bottlenose dolphins capture fish from pens, decimate, and could cause scarring of the farmed fish, increasing fish susceptibility to disease or decreasing growth owing to stress [99]. Potential direct risks to bottlenose dolphins can are represented by entanglement [117], habitat exclusion that results from physical structures [118], or aversive acoustic devices [119].

Bycatch: The US. Ocean Commission in 2005 judged incidental catch (or by-catch) in fisheries the "biggest threat to marine mammals worldwide killing hundreds of thousands of them each year". Fishing gear, especially gillnets, indiscriminately catches an undetermined number of marine species, including dolphins and porpoises. In the Mediterranean the species most affected by interactions with fisheries appear to be sperm whale and striped dolphin. Bottlenose dolphins are also bycaught in a wide variety of gear while short-beaked common dolphins are caught in high numbers in some fisheries in the Alboran Sea [120]. The fisheries with the greatest level of cetacean-fishery interactions are generally gillnet fisheries. One major driftnet fishery has been banned since 1992, but others continue on a smaller scale, and setnet fisheries are widespread. Illegal driftnet fishing poses a major threat to all of these species [120]. As for the sperm whale, entanglement in high seas swordfish driftnets has caused and continues to cause considerable mortality in this species since (IWC 1994, Pace et al. 2005), possibly reducing their abundance in the Mediterranean [120]. The recorded number of sperm whales found dead or entangled from 1971 through 2004 in Spain, France, and Italy (combined) was 229 [27]. Likewise, large numbers of striped dolphins have been killed incidentally in the high-seas driftnet fishery for swordfish, possibly reducing their abundance in the basin since the mid-1980s and may approach $1 \%$ of the population in the Alboran Sea and the Corsican-Ligurian Sea [121]. The recorded number of striped dolphins killed annually in driftnet fisheries may be in the thousands. Incidental kills of bottlenose dolphins in trammel and gillnets occur frequently in some Mediterranean areas [122] somewhere with incidental mortality rates probably unsustainable [123]. Regarding shortbeaked common dolphins, whose populations have undergone a dramatic decline in abundance during the last decades, and have almost completely disappeared from large portions of their former range - including the northern Adriatic Sea, Balearic Sea, Provençal basin, and Ligurian Sea-[124] other than a reported bycatch of 145-200 common dolphins in the Spanish swordfish driftnet fishery in 1993-1994, the threats posed to common dolphins by accidental killing in fishing gear are virtually undocumented [120].

According to Young and Iudicello [120] while the term "bycatch" describes all types of incidental capture of marine mammals in fishing gear, the expression "incidental mortality" is used when deaths are documented. Cetaceans spend several months each year travelling from one area to another. Because they cross through a number of jurisdictions, the level of protection fluctuates according to their geographical location. Inevitably, animals will pass through areas where cetacean conservation is less of a priority than in other zones and the cetacean protection has largely been left to the domestic regimes of coastal states [120]. 
Pelagic driftnets have been prohibited and their use limited by EU regulations since 2002. However, a reduced Italian fleet still fishes with such gear in an unregulated manner, as does a large Moroccan fleet and the French tonnaille vessels [125]. All of these operations are known to cause substantial cetacean mortality. Still, progress on quantifying cetacean bycatch, evaluating the scale and magnitude of this problem, identifying specific conservation actions, and reducing the mortality has been slow, sporadic, and limited to a few specific fisheries or circumstances [126].

Overexploitation (Unsustainable Fishing): Industrialized fishing has severe impacts on species, habitats and ecosystems [93]. Several major studies have showed that exploitation of marine fish resources can greatly impact the overall health of the targeted stocks and have the capacity to drastically alter their supporting ecosystems $[127,128]$. In addition to causing an overall decline in marine fisheries catches, the excessive effort that characterizes most fisheries has led to landings consisting increasingly of smaller fishes, a result of top predators, and the older individuals within species being targeted and depleted [128]. This has resulted in fisheries increasingly landing smaller fishes, from the lower end of the food web, and thus generating the phenomenon now widely known as 'fishing down marine food webs' $[129,130]$. Interestingly, this now ubiquitous phenomenon is in itself an indication that the great whale, and marine mammals in general are not responsible for the major transformation that marine ecosystems have experienced in the last decades, as marine mammals, if they consume fish at all, concentrate on smaller species, and on the younger stages of larger species (e.g., Etnier and Fowler [131]). Indeed, marine mammals have the evolutionary effect of encouraging rapid growth to larger size in fish (because they are then immune to marine mammal predation), while fisheries have the opposite effect of selecting for the evolution toward small size and low productivity [132].

Several fish resources are highly exploited or overexploited $[133,134]$. Overfishing (both forage species and predatory species that help aggregate food sources) has been cited as a reason for severe population declines for a number of top predators (including cetaceans, $[27,135])$ during the last 50 years with the Mediterranean Sea [136]. In some areas, it has been demonstrated that increased fishing activities and more efficient fishing boats and gear have resulted in the overfishing with consequent decline of some fish species and prey depletion. Conversely, no-take zones have been very beneficial for the fish biomass, and consequently for cetaceans, providing sustainable food resources and ensuring healthy ecosystems. For example, in eastern Ionian Sea coastal waters, around the island of Kalamos, Bearzi et al. [35] reported how a formerly resident and abundant common dolphin (Delphinus delphis) community showed a continuous decline beginning in 1997. As shown by further studies [137,138] the local decline was clearly related to prey depletion and a high risk of local disappearance of common dolphins in the area, unless immediate implementation of fishery management measures, highly realistic.

Human disturbance by boat traffic: Human disturbance represented by commercial shipping, recreational boating and tourism (including unregulated whale watching) may affect cetacean populations through collisions, incidental mortality, underwater noise and other forms of pollution $[66,139]$. Intense boat traffic usually may have a direct and immediate effect, such as injury, death, stress or displacement, as well as changes in behaviour for different cetacean species (fin whale, bottlenose dolphin, beaked whale [140-146]). Vessel density is likely to cause also chronic effects (e.g., changes in distribution) that may affect populations over longer term [147].
The Mediterranean Sea is among the world's busiest waterways and shipping traffic is continuously growing along with the concern for its potential impacts on marine fauna [28,148]. With $30 \%$ of all international maritime traffic originating from or directed to Mediterranean ports or passing through its waters and concentrated within only $0.8 \%$ of the global ocean surface, traffic density is extremely high in the basin. At any moment there are approximately 2.000 merchant vessels of over 100 tons in the Mediterranean, totaling at 200.000 vessels crossing it annually [149]. Mediterranean areas of particular interest due to their shipping and cetacean density are the Strait of Gibraltar, the Pelagos Sanctuary, the area south-west of the island of Crete, the area around the Balearic Islands, the area between Almeria and Nador at the eastern side of the Alborán Sea and the Strait of Sicily [150]. Commercial shipping can represent a significant risk for slow moving species, in particular large species such as fin $[149,151,152]$ and sperm whales [153]. Different types of vessels could be implicated in the accidents (for example, fast ferries, tankers or cargo ships [154]). In the north-western Mediterranean Sea, known collisions essentially concern car-ferries $(62.5 \%)$, followed by merchant ships (15\%), yachts (12.5\%) and high speed vessels (10\%) [155]. The size and speed of boats seems to be directly related to the severity of the wounds on the animals $[156,157]$.

Since the 70's, studies showed that at least 69 large cetaceans were killed from collisions, that is to say 1-2 known cases each year, in the north-western Mediterranean. Nevertheless, the scientific community agrees that this number is severely underestimated (perhaps by a factor of 20-30 according to certain authors) as it only takes into account known collisions [158]. Although the number of whales actually killed is as yet undetermined, estimations have been made of at least $16-20 \%$ of known fin whale deaths being attributable to collisions [159], a rate which is particularly worrying bearing in mind the population's ecological characteristics.

Other sources of disturbance to cetaceans by vessel traffic are whale watching activities. The increasing growth of this industry even in the Mediterranean Sea has led to concerns within the scientific community as to whether the presence of numerous boats and their operation around the animals may have an effect on their behavior and survival. Several studies have shown short-term changes in cetacean behavior in response to whale watching in many of the species exposed (changes in surfacing, acoustic, and swimming behavior and changes in direction, group size, and coordination; [160]) and therefore may represent a threat to some populations [161]. It is more difficult to determine possible long-term negative effects of whale watching activities but some hypotheses were proposed. For example, they may have negative effect on health increasing an animal's energy expenditure or resulting in chronic levels of stress [162,163]; long-term alteration or disruption of essential behaviors, such as feeding or resting, may eventually lead to reduced reproductive rates and fitness in the long-term [144,161,164-167]; finally, boat-related sound can be drown out or "mask" cetacean vocalizations, with impacts on communication [168].

Unregulated whale watching activities may also have a disruptive potential. A remarkable example of the impact of pleasure boating on cetaceans in the Mediterranean Sea is reported by Miragliuolo et al. [169]. A Risso's dolphin pod became the target of an ever-increasing number of pleasure boats near Ischia island (Tyrrhenian Sea, Italy), penned into a coastal enclosure and then surrounded by up to 100 boats. Harassment behaviour by pleasure boaters included heading towards the animals at high speed every time they surfaced, sudden changes of the route, and continuous attempts to approach the animals 
at close distance to take photographs or "interact" with them. All group members seemed to be unable to orientate. High-speed erratic swimming, collisions with each other, spinning and swimming in circles with short inter blow intervals were recorded as clear signs of distress.

Pollution (chemical, marine litter, noise): As far as threats to the marine environment are concerned, pollution is by far the more significant [170]. Its internationally recognized definition for the marine sector was developed by GESAMP [171]: "Introduction of man, directly or indirectly, of substances or energy into the marine environment (including estuaries) resulting in such deleterious effects as harm to living resources, hazard to human health, hindrance to marine activities including fishing, impairment of quality for use of sea-water, and reduction of amenities".

The Mediterranean Sea can be considered a 'sink' for environmental pollutants. Itis affected by numerous substances considered to be environmentally and toxicologically most significant, namely hydrocarbon compounds, persistent toxic substances, heavy metals, radioactive materials and nutrients. Due to Mediterranean enclosed and oligotrophic nature their impacts can be exacerbate [172]. Besides, the introduction of energy (i.e., noise, light, electricity, heat, electromagnetic radiation, or vibrations) in the marine environment changes the physical system and human activities adding a disproportional amount of energy can have (and increase) negative impacts on marine biodiversity.

Chemical: Mediterranean long-lived top predators in marine ecosystems, and particularly cetaceans, are most exposed to toxic effects and more vulnerable than other organism slow down in the food chain to the accumulation of high concentrations of anthropogenic contaminants [173], many considered Persistent, Bioaccumulative and Toxic (PBT) [174]. Since dolphins and whales are less able than other mammals to metabolise heavy metals, organochlorine compounds (OCs)-such as polychlorinated biphenyls (PCBs), dichlorodiphenyltrichloroethane (DDT), hexachlorobenzene (HCB) and dioxins, polycyclic aromatic hydrocarbons (PAHs), and other environmental contaminants, their pollutant burden is high, amassing important concentrations of toxic substances in their tissues, even passing them to infants through mother's milk. There is still no evidence that PBT chemicals are causing direct mortality of cetaceans, however it is certain that lipophilic contaminants cause immune and reproductive dysfunction $[175,177]$. For example, the well-known immunosuppressive effects of OCs such PCBs in mammals suggested that these substances impaired immune responses and increased the severity of the outbreak [178]. OCs are also known to be endocrine disrupting chemicals (EDCs) [179].

OCs can be found with very high levels in the Mediterranean basin, despite regulations and controls of their production and use [180]. However, their levels seem to be decreasing [178], while contaminants such as organobromine compounds (Polybrominated Diphenyl Ethers, PBDEs) seem to be increasing in the environment [181]. Used as flame retardant, PBDEs are lipophilic, persistent and toxic to wildlife and humans $[181,182]$. The highest levels of PBDEs have been recorded in top marine predators, including Mediterranean odontocetes [183].

Another important class of contaminants for cetaceans is PAHs, the most toxic family of hydrocarbons. They are released in the environment by natural (e.g., oil spill, forest fires, natural petroleum seeps) and anthropogenic sources (e.g., industrial processes, combustion of wood and fossil fuels, motor vehicles, incinerators, oil plants and refineries, oil spills). Particular concerns relate to their genotoxicity; a correlation is thought to exist between high levels of certain PAHs in the environment and an increased incidence of carcinogenesis and mutagenesis in exposed organisms [184,185].

Important factors for bioaccumulation are also metabolic rates, gender, age and adipose tissue concentration. The ecotoxicological risk of some species is also related to their "biochemical vulnerability" to lipophilic xenobiotics due to the low capacity of their detoxifying enzymatic systems $[186,187]$. Since the incidence of pathology in these species is nearly related to the pollution's levels in their environments, bacterial and viral infections and contaminants must be considered interdependent parts. Mass mortalities of cetacean species have occurred in particularly polluted areas (such as the Mediterranean Sea), when levels of OCs, PAHs and heavy metals reached very high levels [188].

The last decade has seen major successes in terms of global measurement and regulation of PBTs [189]. There has been a major expansion of monitoring and risk assessment for new chemical contaminants in the global environment, PBDEs and perfluorinated alkyl acids (PFAAs). However, the list of measured chemicals represents only a small fraction of the approximately 30.000 chemicals widely used in commerce [189]. Currently there are little information on the levels and especially the effects of these emerging contaminants for cetaceans and also the synergistic effects of mixture of them [174].

Marine litter: The continued accumulation of debris in marine environment represents a growing global issue and a major threat to marine biodiversity (e.g., CBD [190]). From the benthic environment to the pelagic zone, the whole spectrum of marine habitats is under pressure from its affects [191]. It has the potential to effect all trophic levels and for impacts to travel through the food chain, from planktonic microorganisms through to marine megafauna [192-194].

According to Chesire et al. [195], marine litter includes any manufactured or solid waste entering the marine environment irrespective of the source. It can be categorized into several diverse classes of material including plastics (e.g., soft, foam, nets, ropes, buoys, monofilament line and other fisheries related equipment, smoking related items such as cigarette butts or lighters), metal (e.g., drink cans, bottle caps, pull tabs), glass (e.g. buoys, light globes, fluorescent globes, bottles, etc), paper, rubber and cloth. The range and scale of impacts on marine mammals are diverse (see UNEP [196]) and may include entanglements and ghost fishing, ingestion with consequent intestinal blockage, malnutrition and poisoning, blockage of filter feeding mechanisms from small particulate plastic debris, physical damage until the death of marine animals. Recently, Baulch and Perry [197] find that ingestion of debris has been documented in 48 (56\% of) cetacean species, with rates of ingestion as high as $31 \%$ in some populations. Debris-induced mortality rates of $0-22 \%$ of stranded animals were documented, suggesting that debris could be a significant conservation threat to some populations. However, difficulties remain in linking the effects of debris at a physiological or individual level to population level impacts [198].

Three billions of litter items float or cover the sea bottom in the Mediterranean Sea, which $70-80 \%$ is plastic waste $[199,200]$. However, despite legislative requirements, still few data are available in the Mediterranean on marine litter distribution, composition and source. There is also a lack of knowledge on sensitive areas where the potential damage to the biota is greater due to the overlap of debris and cetaceans [147]. A growing concern is especially for deep water suction 
feeders, i.e. Cuvier's beaked whale, Risso's dolphin and the endangered sperm whale, since variation in distribution of plastic debris overlap with squid-eating species presence in specific seasons within sensitive areas in the central Tyrrhenian Sea, Sardinian Sea and the Spanish continental shelf [147].

Plastic can degrade to microscopic pieces [201]. Microplastics (MPs-generally defined as fragments less than $5 \mathrm{~mm}$ in dimension) floating on the Mediterranean Sea have reached 115.000 particles per $\mathrm{km} 2$ with a maximum of 892.000 particles [192]. Due to high sorption capacity for hydrophobic organic chemicals, the adherent chemicals can be transported by MPs travelling long distances [202]. MPs can serve as carrier of persistent organic pollutants (POPs) such as PCBs, PAHs, DDTs, PBDEs, alkylphenols, and bisphenol A in marine ecosystems [203,204]. Planktonic plastic loaded in organic pollutants can easily be mistaken for prey and upon ingestion the pollutants bioaccumulate [205]. A wide range of organisms, from plankton to larger vertebrates such as whales, may ingest MPs (Wright et al. 2013) but impacts to organisms and the environment are largely unknown. It is recognized that microplastics are accumulating at the sea surface, especially within the neustonic habitat [206] that included a specifically adapted zooplankton fauna (e.g., fin whale). Fin whale, being characterized by a long life span, could be chronically exposed to these persistent contaminants both leaching from microplastic ingestion and degradation and through the food chain. Fossi et al. [207] studies on the Mediterranean fin whale in the Pelagos Sanctuary demonstrate for the first time microplastic ingestion by cetaceans. The mean abundance of microplastics in the Pelagos Sanctuary in the Mediterranean was found to be of the same order of magnitude as that in the North Pacific Gyre, with particularly high levels in the Ligurian Sea and it is hypothesized that fin whales could consume 3.653 microplastic particles per day, along with associated persistent, bioaccumulative and toxic (PBT) chemicals [207].

Noise: One of the most serious threats to cetaceans worldwide, but also one of the most difficult ones to properly address, is underwater noise pollution. Due to boat and ship marine traffic, military activities, seismic exploration, construction, etc., in the Mediterranean Sea the increasing levels of noise interfere with their sophisticated hearing systems severely harming these species $[62,208]$. Noise pollution can cause marine mammals to abandon their habitat [209] and/or alter their behavior by directly disturbing them [145], by impairing their ability to communicate and to locate their prey or by masking their acoustic signals over large areas [210]; loud sounds may directly affect their hearing abilities by producing either temporary or permanent hearing loss $[211,212]$. All these effects may be critical for the survival of marine mammals even causing injury and death. Some high-energy sound sources can have immediate impacts and trigger mortality events, as evidenced by atypical mass strandings of beaked whales in Greece in 1996 [43].

As underlined by Southall et al. [213], the range of potential impacts depends on spatial relationships between the sound source and the animal receiver, its sensitivity, the exposure level, duration and duty cycle and many other factors (see also Richardson et al. [211]). The same acoustic source may have radically different effects depending on operational and environmental variables, and on the physiological, sensory, and psychological characteristics of exposed animals. For example, Ziiphids are thought to be the most susceptible to acoustic disturbance of seismic surveys due to their habitat of occupying underwater canyons where sound attenuation is thought to be less [43]. Moreover, the animal variables may differ among individuals of a species and even within individuals depending on various factors (e.g., sex, age, previous history of exposure, season, and animal activity). Responses elicited can depend both on the context (feeding, mating, migrating, etc.) in which an individual is ensonified and on a host of experiential variables [214]. Few studies have been able to quantify the long-term effects on cetaceans of exposure to man-made marine noise. Whilst brief or single acute exposures to sound may injure individual animals, long-term continuous noise from multiple sources is potentially more serious as it could cause changes to behavior and habitat use that could affect whole populations [215].

The seismic survey conducted by the oil and gas industry and (to a much lesser extent) geological surveys is one of the most regulated sources of noise [216]. These surveys employ airguns that produce sharp, loud sounds that cannot be precisely controlled and include energy at frequencies as high as $22 \mathrm{kHz},[217,218]$. The majority of the noise energy, however, is at frequencies below 100 or $200 \mathrm{~Hz}[218,219]$ that may propagate over distances as large as $4.000 \mathrm{~km} \mathrm{[220]} \mathrm{and} \mathrm{are}$ used heavily by baleen whales in their own sounds [221,222]. Behavioral reactions to these exposures are generally variable, contextdependent and not easily predictable. An animal detecting one kind of signal may simply orient to hear it or viceversa might panic and flee. There is no evidence to support or refute the 'common sense' supposition that marine mammals swim away from the source; no studies to date have investigated this systematically [223]. DeRuiter et al. [224] illustrated that, in many cases, airgun received levels will not decrease monotonically with increasing range, so that a simple spreading law will not accurately predict the observed pattern of received levels at increasing distances from the sound source. These acoustic 'shadows' may actually lead to an animal approaching the survey vessel. Alternatively, animals may ignore or tolerate the increasing airgun noise, perhaps to remain in a food-rich area [223]. This behavioral habituation and/or physiological acclimation could lead to the animals remaining physiologically non-responsive until, perhaps, exposures reach potentially dangerous levels $[225,226]$.

Genetic erosion: Increasing documentation of changes in the abundance and distribution of species in the Mediterranean provides evidence of anthropogenic pressures or natural causes impacts, yet surprisingly little empirical work has endeavoured to quantify how such recent and rapid changes impact genetic diversity for species persistence and phenotypic plasticity or adaptive capacity [227-229].

Studies to date have indicated a complex pattern of population genetic structure for most cetacean species investigated in the Mediterranean Sea, with suggestions that habitat diversity plays a significant role in driving and shaping the genetic structure of cetacean populations [230-232]. Seasonal patterns of movement and the possibility of extremely large-scale dispersal, or local isolation (sympatric or parapatric) between populations, generate a mosaic of genetic diversity that cannot easily be determined by an intuitive assessment of Mediterranean geography [188]; processes involved in defining the genetic differentiation of these highly mobile marine mammals remain still largely unknown [232].

Genetic diversity generally underpins population resilience and persistence, appearing to be a major factor determining the success and long-term potential for survival of a species in harsh, changing environments [233]. Exposure to factors that can affect survivorship, recruitment, reproductive success, mutation rates, gene flow and migration may play a significant role in partitioning genetic variation among high stress exposed populations [234] and this seems particularly true for cetacean populations inhabiting the closed 
Mediterranean basin [188]. For example, previous studies showed evidence of clear genetic differentiation between Atlantic and Mediterranean populations of striped dolphin and found much lower genetic variation of Mediterranean specimens [47]. Gene flow through the Gibraltar Strait appears to be limited and easily prevents the genetic exchange between the Atlantic and Mediterranean cetacean populations.

One reliable indicator of the risk that a given species loses genetic diversity is the effective population size (it is inversely proportional to the impact of genetic drift, i.e. the main process leading to fixation and loss of alleles and therefore to the loss of evolutionary potential). Conditions that may cause decreases in population size, such as bioaccumulation of pollutants, immunosuppression, infectious diseases, climate change, and food depletion could soon lead to a drop in total genetic variability of Mediterranean cetacean species [188], increasing the risk of extinction for fragmented and threatened populations $[235,236]$.

Intentional killings: Commercial whaling never took place in the Mediterranean, probably because whales had always been presumed to be too rare to warrant the effort [237]. One exception to this is represented by the whaling activities carried out in the Strait of Gibraltar and adjacent waters, possibly including the westernmost portion of the Alborán Sea, which begun in 1921 [238]. Balaenoptera physalus, Balaenoptera borealis and Physeter macrocephalus were the object of a very successful whaling industry [239-241]. However, by 1926, with over 4.150 fin whales killed in a few years [241], the population had collapsed and the operations declined due to lack of whales [240].

Today, cetacean mortality due to intentional killing seems to be still an issue, but limited to the smaller species (Tursiops truncatus, Stenella coeruleoalba and Delphinus delphis) [238]. Animals with lethal amputations or gunshots are not rare in Mediterranean stranding reports. Although the causes of these deaths can vary, and may include collisions or "sport" killings, the large majority of intentional takes arise from deliberate slaughter of individuals regarded as vermin by fishermen, and occasionally from the use of cetacean meat for human consumption or bait [124].

As reported by Notarbartolo di Sciara and Bearzi [238], coastal dolphins-particularly bottlenose dolphins-are often claimed to steal fish from the nets, scare the fish away, or damage the catch and fishing gear. This may result in actions ranging from a variety of attempts to keep the animals away from the nets, to intentional killings carried out with guns, harpoons, explosives, or poisoned bait [123,242,243]. As the evidence of direct killing is mostly provided by a dead cetacean stranded or adrift, it may be difficult to assess with certainty the prime cause that prompted the killing, whether perceived competition, game hunting, or else.

For instance, in the Italian seas, between 1986 and 1990, 10\% of the confirmed causes of death among stranded animals have been related to direct killings. The species that were most frequently affected were the striped dolphin and the common bottlenose dolphin, with a few cases involving other species [244].

\section{How to preserve cetacean value?}

The future of Cetaceans and of the values represented by their diversity and ecological role will be determined by humans' current and future actions. The promulgation and implementation of integrated management plans as well as the execution of combined actions for the conservation of these species (with the endangered ones as a priority) and their habitats should be an urgent, strategic priority worldwide. In the Mediterranean, emphasis should be on:

Improving existing knowledge on cetacean populations; in particular:

- Undertake comprehensive surveys to obtain reliable estimates of their abundance/size and distribution.

- Advance understanding of climate change impacts.

- Progress understanding of, and response to, pollutants, diseases and die-offs in populations.

- Increase understanding of predator-prey relationships under an ecosystem approach to fishery management.

Creating a more participated legal, institutional, civil and scientific approach to coastal development, marine resource exploitation, fishing techniques, and protected sites and species to ensure that cetacean population are fully covered and preserved; in particular:

- Enforce the existing national and international legislation.

- Increase efforts to identify and establish conservation areas that cover the full range of resident or frequently visited sites for the various cetacean species.

Implementing mitigation procedures specifically designed to prevent, sustainably manage and reduce the negative impacts from cetaceans' interactions with human activities, both at individual and population level; in particular:

- Harassment by noise generating activities (such as seismic surveys, drilling, pile-driving, etc.,).

- Disturbance/collisions due to vessel traffic (such as leisure boating, whale watching activities, commercial shipping, etc.).).

- Deliberate/undeliberate killings in fishing gears (such as bycatch, depredation, etc.,).

Spatial planning and marine protected area designation to prevent habitat loss, degradation, and disturbance to cetacean populations. Developing a comprehensive communication, outreach and education strategy to engage people on cetacean conservation and promote responsible viewing of wild cetaceans by tourists and commercial operators (encouraging eco-friendly tourism and whale-watching).

Identifying and implementing other specific measures under precautionary principles; in particular:

- Reductions in fishing effort or seasonal closures of particular fishing areas.

- Decreases in inputs of degradation sources of the marine environment (particular pollutants or debris).

Some of these Mediterranean priorities are discussed below.

\section{Improving existing knowledge: research and monitoring}

Continued investment in research and monitoring is essential to better understand why and how biodiversity and cetacean populations are changing in the Mediterranean Sea, the consequences of these changes, to predict likely future change, and to design and test approaches to managing marine biodiversity. A good evidence base is needed to guide decisions and help to make sure we are doing the right thing in the right place, and well using our resources, focusing on action that will have the most impact. 
The lack of scientific knowledge on cetacean ecology, biology, pressures and impacts in the Mediterranean area is one of the greatest disabling factors for the elaboration of conservation measures. Scientific innovation, new techniques and combined researches and monitoring activities are necessary to potentiate conservation efforts on cetaceans and must be planned understanding the local priorities and coordinated from regional to national scale.

Sound research and worthwhile data collection should be developed and implemented in the Mediterranean Sea in order to fill information gaps and improve our knowledge on:

- Population ecology and habits of the regular species (size, trend, degree of gene flow across populations, etc.,).

- Abundance, distributions and time variability of species not assessed/data deficient and in poorly known areas.

- Short and long-term effects of noise levels (seismic prospection, military sonars, vessel traffic, other noisy activities at sea).

- Disturbance from commercial, military, pleasure boats, whale watching and research activities.

- Depletion of food resources due to overfishing and illegal fishing (exploitation rates).

- The contribution of mortality factors to the death rate of the cetacean populations (incidental mortality in fisheries, ship strikes, epizootic diseases, direct killings, etc).

- Ecosystem changes (implementation of techniques based on multitemporal, multi-spectral, satellite-sensor data collectors).

Further research on technological innovations (e.g., quieter propulsions to reduce vessel noise, systems to reduce the risks of collisions between cetaceans and ships, instrumentation to reduce cetacean bycatch) should be also encouraged. Moreover, critical habitats for each population must be detected, understanding populations' basic needs, environmental health, and levels of disturbance. A geographic representation of the distribution of the man induced pressure factors that impact on cetaceans should be mapped with the identified critical habitats in the basin (following Halpern et al. [4]).

A large body of literature exist that review research methods on cetaceans (e.g., [245,246] Dawson et al. [245]; Mann et al. [246]), most of them also suitable to collect data for management and conservation efforts. Monitoring abundance, distribution and density of cetaceans can be executed by dedicated line-transects surveys and long-term studies based on photo-identification techniques. Passive acoustics could be simultaneously performed by means of listening devices located on the ship, buoys or bottom-mounted. The same systems can be used to monitor noise levels in the marine environment. A synoptic, region wide survey with uniformity of methods has not been performed yet and only localized, heterogeneous survey campaigns were conducted in the Mediterranean Sea (mainly through the effort of research groups and NGOs).

Radio, satellite and acoustic tagging and tracking of cetaceans using satellite archival, transponder or acoustic tags collect data on location, depth, temperature, and body movement, to answer questions about migratory patterns, seasonal feeding movements, daily habits. Shortterm, passive tracking of individual cetaceans near a research platform could be also been performed using laser range-finders linked to a Global Positioning System (GPS).

The collection of tissue samples through remote biopsies from free ranging cetaceans is central to an integrated multidisciplinary approach [188]. Their use in research and monitoring seem to be a powerful procedure to screen a large number of samples, with a minimal disturb to animals, and a robust tool for the comprehensive diagnosis of multiple stress factors, health status and genetic population variability. DNA from skin samples is used to identify individuals (genetic mark-recapture), to estimate population size, study group structure and gene flow between populations. Skin samples are also collected for stable isotope analysis for understanding animal's diet, trophic level, foraging habitat (near/offshore) and nutritional stress. Blubber samples are analysed for hormones (progesterone is correlated with pregnancy status, testosterone with male sexual maturity, while cortisol gives information on the stress conditions of the animal), and for contaminant loads (POPs) to evaluate reproduction and survival status [247]. Detoxifying capabilities could be understood by applying biomarker techniques to tissues grown in the lab after culturing of cells secured through biopsies.

Finally, rescue units to help animals in difficulty and coordinated stranding networks to monitor strandings along the Mediterranean coastal area are needed. Twenty riparian countries are contributing with their data to MEDACES (medaces.uv.es) but the $92 \%$ of the stranding events were contributes only by 5 countries [248]. All we know about many cetaceans' species is limited to what was learned from strandings (e.g. many beaked whales). Every stranding should be considered a unique opportunity to collect data on anatomy, life history, genetics, disease, parasites, predators, contaminants and feeding ecology [249]. Stranding data should be made available to the scientific community (securing and centralizing them as for MEDCES database) and the institution of "tissue banks" should be implemented (improving studies on genetic, population dynamic and health, pathology).

\section{Implementing mitigation procedures: examples on collisions and acoustic noise}

Input and advice from scientists, conservation and environmental groups, government agencies, and industries (fishing, shipping, oil and gas, etc.,) are needed to collaboratively develop mitigation solutions that will lead to a quantifiable reduction in potential threats to cetaceans in the Mediterranean Sea.

Collisions: Ship strikes are an international problem that requires improved knowledge of the behaviour and movements of cetaceans and vessels, and a much better understanding of the numbers of collisions and the circumstances surrounding them. All mitigation work needs to be undertaken in a collaborative way as migratory animals like whales travel across national boundaries. For instance, the International Whaling Commission (IWC) is working in conjunction with other organisations such as the International Maritime Organisation (IMO) and have produced an information leaflet with further advice to reduce the risk of collision (available at: https://iwc.int/ship-strikes).

There is no universal solution to the problem of ship strikes and different technological, operational and legal/voluntary solutions are all currently being explored [250]. In the Mediterranean Sea, to reduce the risk of ship strikes in the Pelagos Sanctuary, a technological solution called REPCET (REal-time Plotting of CETaceans) system was created in 2009 [251]. It is a collaborative client-server system through which equipped ships can transmit the positions of the whales they encounter to one another via satellite or internet connection. When a 
whale position is received, a risk zone appears on the screen and grows with time to a certain radius and at a certain speed according to our knowledge of whales' swimming speed in the area. When a ship enters a risk zone, a visual or acoustic alarm is triggered and crews are recommended to increase their watch and reduce speed. Other technological solutions as mitigation measures to prevent ship strikes and minimize the risk of collisions with cetaceans may include heatdetecting devices, infra-red and other enhanced optics, SONAR or other forms of 'active' acoustics, passive acoustics, satellite imagery and satellite tagging. Even these technologies may have application in this context, none is judged fully capable of addressing the problem in their present form [250]. At the moment, the most effective way to reduce collision risk is to keep whales and ships apart, and where it is not possible to separate whales and vessels through routing measures, intensification of watching efforts and restriction in speed are the most effective way to reduce lethal strikes [252-254]. There is good scientific evidence that the risk to whales is substantially less from ships travelling at 10 knots, with a significant reduction of the probability of fatal ship strikes by $90 \%[157,252,255$, $]$. It is therefore important to inform the shipping industry of the success of the speed reduction measures in order to confirm their value and to further encourage compliance. Furthermore, it is essential produce high quality data to better define the problem and the expected effects of any mitigation, both in term of risk reduction for cetaceans and the consequences for vessel routing.

Acoustic noise: As previously described, marine seismic surveys are known to generate acoustic noise that disturbs and could harm marine life. Given the expansion of these surveys and their potential for negative environmental impact, there is a growing need for systematic planning and operational standards to eliminate or at least minimize effects, especially when surveys occur in sensitive areas (e.g., those containing endangered species or critical breeding/feeding habitat for multiple species or large numbers of individual organisms) [256].

The Joint Nature Conservation Committee (JNCC) with its "Guidelines for Minimising Acoustic Disturbance to Marine Mammals from Seismic Surveys" became the first regulatory body in the world to establish rules to address these issues [257]. More relevant to the prevention of injury rather than disturbance [258], nevertheless, these guidelines became statutory in the UK in 2001, filled a policy vacuum and have since been adopted, in whole or in part, by several other management agencies around the world. Despite limited refinements the mitigation measures remain largely unchanged [258] essentially condensing down to two basic elements: maintenance of a pre-survey safety zone-a fixed area of $500 \mathrm{~m}$ radius from the centre of the airgun array, scanned before the commencement of the soft-start and determined to be clear of marine mammals-and mitigation sources.

A special attention deserves the involvement in mitigation programs of Marine Mammal Observers (MMOs), trained operators whose main role under JNCC guidelines [258] is to search for marine mammals within a mitigation zone. Passive Acoustic Monitoring operators (PAMs) supplement visual surveys solving the issue of detecting marine mammals that are underwater or in case of scarce visibility such as in bad weather and night. Both these qualified professionals are effectively responsible for compliance as well as monitoring, but, as recently underlined by Wright and Cosentino [216], their role is at the moment "purely advisory," as they can only recommend a mitigation measure if marine mammals are detected [258].

While mitigation-the historical focus of operational protocolsrepresents the actions designed for and implemented during the survey to counteract the immediate impacts on animals in the area, measuring and understanding reactions in a systematic way is in fact another important aspect of any responsible program. In effect, an important distinction exists between monitoring and mitigation with the former that applies to a program for collecting data both to test for effects after the seismic survey has concluded and to apply the results to the planning of future campaigns Nowacek et al. [256].

Depending on local environmental parameters, the characteristics of species potentially affected and the history and nature of other operations in the area, no two surveys will be exactly alike. However, according to Nowacek et al. [256] recent advances in technology and experiences make it possible to establish a generalized approach based on primary components critical for a substantial monitoring and mitigation program able to assure more environmentally responsible marine seismic surveys. These elements are:

- The assessment of background data with respect to species of concern (habitat, habits, life history) and environment (bathymetry, sound propagation).

- Spatial and/or temporal restrictions and requirements.

- The generation of acceptable exposure criteria.

- Mitigation measures: which to use and how/when they will be implemented.

- The understanding of the acoustic footprint of the survey: modeling of the acoustic source and the propagation environment.

- The pre-survey validation of source and propagation models.

- The selection of appropriate techniques for implementing mitigation and monitoring elements (e.g., visual or acoustic survey methods).

- The creation of robust communication plan, including explicit chain of command;

- The post-survey assessment of mitigation measures.

- The publication of monitoring data to describe effects or lack thereof, and to improve mitigation and monitoring of future surveys.

Such a program requires a broad collaboration, led by company representatives but with meaningful input from scientists with relevant expertise as well as government regulators, the seismic contractors, vessel owners, and NGOs.

\section{Marine protected areas}

Cetacean protection can help support ecosystem-based conservation and its expansion in management applications, serve as indicators of ocean health and ecosystem degradation [18,259], and provide opportunities for regional collaboration [18], such as through the development of regional networks or transboundary sanctuary agreements for migratory species as well as Marine Protected Areas (MPAs).

The establishment of protected areas is a widely used measure for the preservation of biodiversity and MPAs can be an effective conservation tool for cetaceans [260,261]. However, there has been little evidence that MPAs have been successful in improving demographic parameters of marine mammals, as many years of data are often required to detect any meaningful biological change. The first evidence that MPAs can work for cetaceans is from a 21-year study undertaken in Banks Peninsula Marine Mammal Sanctuary, New Zealand [262]. The authors, empirically examining the efficacy of 
MPAs for marine mammals, definitively provide evidence that areabased protection methods can be successful for cetaceans.

MPAs for cetaceans require targeted management measures to address marine mammal and ecosystem threats either as part of the MPA itself or through existing laws and regulations. Currently, in terms of conservation of most cetacean populations, MPAs are too small, too few in number, and too weak in terms of protection, and most are "paper reserves"-MPAs in name only [263]. Yet MPAs hold some promise for marine species and ecosystems when they include substantial highly protected zones, use ecosystem-based management (CBM) principles, and function as part of larger MPA networks. It has been suggested that the network approach is a step beyond creating individual MPAs: through interconnections and interdependencies, individual MPAs of this network contribute positively to each other's integrity by decreasing overall vulnerability [208]. Networks accommodate the needs of many ocean species that travel during their life histories, such as cetaceans which migrate or, in some cases, travel in search of food or mates. In addition, cetaceans depend on food webs whose critical habitats may be widely separated. MPA networks help deliver the mandate of ecosystem-based management (i.e., a regime to manage the uses and values of ecosystems with all stakeholders to maintain ecological integrity in the face of the uncertain and ever changing nature of ecosystems) as they allow essential ecosystem processes and the important features of complex marine ecosystems to be protected [263].

All marine protected and managed areas in the Mediterranean cover approximately $4 \%$ of the surface. There are 38 MPAs with cetacean habitat, including one on the high seas, and a number of smaller protected areas. Being coastal, the bottlenose dolphin is the most common conservation objective. MPAs for cetaceans in the Mediterranean display many weaknesses: lack of representativeness of critical habitats, lack of stakeholders' involvement, inadequate management, and lack of data on status of species and habitats [264]. Defining critical habitat for cetaceans is difficult, but there is recognition that habitat-use data can show hierarchies of importance evidence for discernible habitat preference within an animal's broader range can reveal areas essential to a population's survival $[34,36,37,265]$ - and these high-use marine areas can be targeted for protection. Critical habitat refers to those parts of a cetacean's range, either a whole species or a particular population of that species, that are regularly used for feeding, breeding and raising calves, as well as, sometimes, migrating, are part of critical habitat [263]. Yet marine critical habitat boundaries may be less fixed, especially in terms of hunting and feeding areas, which are dependent on upwelling and other changing oceanographic conditions. The implication for MPA design is that more flexible definitions of marine protected areas for cetaceans are needed in some cases, with zoned protection that can be adjusted as needed from year to year or even within seasons to accommodate uncertainty. To achieve such fine-grained critical habitat management, it will be necessary to unravel and understand ecosystem processes and the impacts that humans can have on such processes. An appropriate tool for this is ecosystem-based management [264].

At a time of biodiversity decline and the rapid spread of anthropogenic impacts there is a need to accomplish more, using the best-available scientific data to ensure persistence of populations and habitats of marine species and ecosystems. An important step forward the paradigm of MPAs for marine mammals has been the introduction of the concept of important marine mammal areas (IMMAs). Identifying IMMAs will lead not only to more MPAs and MPA networks but better marine spatial planning (MSP), as well as enable risk reduction of ship strike, noise, bycatch and other threats, and help with monitoring for climate change [266]. A starting point for considering Important Marine Mammals Areas (IMMA) criteria to protect single species or a combination of species are [267]:

- Reproductive areas and times

- Feeding areas and times

- Migration corridors

- Smaller or resident populations

- Abundance estimates and population structure (with consideration of rarity, uniqueness, genetic isolation, irreplaceability, size of populations, and temporal aggregations)

- 3D habitat features

- Considerations of vulnerability and resilience

In the pelagic realm frequented by cetaceans, it is likely that at least in some instances site-based conservation approaches are not going to be sufficient, or even suitable [267]. However, IMMAs, being a new development, provide an opportunity to explore how static notions of MPAs can merge with more flexible modern management interventions, supporting 'dynamic ocean management' [268,269]. Various data streams, such as from tracking and remote sensing technologies, could conceivably be fused together to support near realtime decision-making on where a given IMMA is and in which direction it is headed [267].

\section{Communication and education}

Cetaceans play an important role as flagship species. They put a tangible face to anthropogenic threats in the marine environment, increasing public awareness and political will to mitigate such threats and providing a focal point around which broader marine conservation objectives can be achieved.

Communication and education have the potential to unlock actions on cetacean conservation. To be successful, communicators must use science and policy wisely, to develop powerful messages that inspire people about, and induce protection actions on, sea life. The challenge is to make marine biological diversity concerns a part of how people manage the planet in all sectors. Conservation efforts will ultimately succeed only if the people living in the animals' habitats adopt them.

Education and awareness are long-term investments towards such social change. Communication campaigns are critical elements of effective management, and need to be handled at the highest professional level to be strategic, positive and tailored to different circumstances and cultural situations. Approaches need to be customized to the local context, culture and traditions. Withal, international experiences can teach national projects in develop community-specific actions. For example, awareness on the very existence of cetaceans, their value and threats, is still very low in the Mediterranean area, and varies from country to country.

Researchers have a key role to inform the greater public about the status of cetaceans in the Mediterranean, the effects of human activities and pressures on their health, and solutions to improve their chances of survival. However, researchers often believe that scientific evidences are persuasive arguments in themselves, not considering that scientific knowledge does not automatically inspire people to modify their attitudes and behaviour. Scientific contents have to be translated into concepts that appeal to public and stakeholders, messages that are relevant to them, linking with their emotions and personal benefits. 
Experts find hard to comprehend the different impressions that exist among different interlocutors. This requires expertise in communication and social science professionals. Awareness can be realized by ensuring that the media operators are trained and updated on cetacean conservation matters, developing educational material and programmes. Such activities are particularly adequate to NonGovernmental Organisations (NGOs) concerned with cetacean conservation, and best results can be achieved through a co-operative effort between institutions and NGOs themselves.

\section{Eco-friendly tourism development and whale watching: lights and shadows for cetacean conservation}

Ecotourism is defined as leisure travel that provides tourists with an educational and conservational experience visiting complex and fascinating ecosystems and their associated species, cultures and traditions. Ecotourism should have a minimal impact on both the environment and the culture and inform tourists about what's needed to sustain the environment they are visiting. Ecotourism can also help foster a sense of environmental stewardship by encouraging travellers to be mindful of wasting resources and polluting the environment and can also help local economies by generating revenue and jobs, which further encourages the local population to preserve its environment. Although the overall concept and intent of eco-friendly tourism is positive, the industry is not without its critics largely due to companies who abuse the concept of ecotourism to take advantage of the wealth generated by the interest in ecotourism.

The practice of observing cetaceans in their natural environment (or whale watching) falls within the realm of ecotourism. It focuses on the aesthetic consumption of these creatures through the process of a largely visual experience that is supposed to be educative in nature [270], encouraging people to appreciate and preserve them. Encounters with cetaceans create a need within people to help protect them [271], and has the potential to benefit conservation from the long-term effect of changing attitudes towards wild animals and natural habitats. Whale watching also provides the opportunity to educate people about other environmental issues affecting marine environment, such as overfishing and pollution, and can act as a platform from which commercial tour operators can educate their tourists.

Whale watching is developing into a significant industry in many countries worldwide [272]. It is estimated that 13 million people went whale watching cruises and flights globally in 2008 . Whale watching generated US $\$ 2.1$ billion per annum in tourism revenue worldwide and employed around 13,000 workers [273]. Other estimates have put this as high as 18,000 [274]. Significant further economic benefits can be expected from an expansion of the whale watching industry as an opportunity for many communities around the world [275]. Whilst the circumstances of these communities are often very diverse, the goal of sustainable whale watching, conducted in harmony with healthy cetacean populations in a healthy environment, must be a shared one.

Whale watching is not without its own impacts (in particular causing a reduction in biologically important activities [276]). It often targets specific cetacean communities that are repeatedly sought out for prolonged, close-up encounters, with impacts on individual whales, their populations and their habitats. It is hard to disentangle the combined effects of noise and physical presence [277,278] of an increasing number of whale watching vessels. Short-term changes in the behavior, such as alterations/disruption to feeding strategies, reduced maternal care, or surface-active behaviors (SABs) modifications, in the long-term can lead to the displacement from preferred habitats or reduced reproductive success [279]. In addition to altering behavior, masking communication, or displacing animals, whale watching tourism can also have more direct impacts. Whales have been injured or killed as a result of collisions with whale-watching vessels, especially in areas where there is a high intensity of whalewatching traffic [280]. Whale watching management therefore encompasses macro, meso and micro dialogues that contribute to the way we view whales on the global and local levels [270].

Many scientists, governments, NGOs and the whale watching industry are working together to assess threats, identify and share best practice, and support responsible, sustainable whale watching avoiding too much interference with the whales. A variety of strategies has been implemented in an effort to manage and control whale-watching activities in different locations worldwide. These strategies include regulations/guidelines (for a review, see IWC [281]), permit and licensing systems, industry guidelines, education, and interpretation. The introduction of guidelines or regulations has been the most common method of trying to mitigate the impacts of boat-based whale watching. Most codes of conduct are entirely voluntary and seem to have greater acceptance when whale-watching operators and tourism organizations are consulted extensively during the drafting of the guidelines (bottom-up approach; [160]). Regulations for minimum approach distances (e.g., 50-100 m or more) are included in almost all codes but most do not curtail especially invasive activities, for example, no proscriptions on feeding cetaceans and do not prohibit touching cetaceans [280]. In any case, the existence of guidelines, regulations, or laws in an area is no guarantee of compliance with these guidelines. It has been suggested that codes of conduct should be modified if necessary as new biological information emerges [282]. An important component supporting this management system is research, to assist in ensuring that activities do not have a significant adverse impact on the behaviors and fitness of individual cetaceans or populations, or on their habitats.

One operational method for reducing the impacts of whale watching is to establish "refuges" that is, "no-go" or "sanctuary" areas. Ideally such areas would allow animals to engage in biologically important behaviors (e.g., feeding, resting, or nursing) without being disturbed by whale watching vessels. Refuges could be spatial (e.g., a marine protected area limiting whale watching traffic), or they could be temporal (e.g., prohibitions on whale watching activity in a location at certain times of day, days, or seasons [263].

\section{Conclusions}

The aim of this review was to provide an overview of the Mediterranean diversity and conservation status of cetaceans, and the value associated with their conservation and non-consumptive use.

Mediterranean Sea is an exceptional habitat supporting a high diversity of marine fauna and offers a unique opportunity to conserve biodiversity that is increasingly under threat in the whole region. Pressures on the species inhabiting the basin are not inconsequential and are likely to be exacerbated in the coming decades. Thus, despite the plethora of initiatives, major challenges face Mediterranean biodiversity and key species conservation, including cetaceans. These comprise the need for spatial prioritization within a comprehensive framework for regional conservation planning, the acquisition of additional information from data-poor areas, species or habitats, and 
Page 17 of 24

addressing the challenges of establishing transboundary governance and collaboration in socially, culturally and politically complex conditions.

Cetacean susceptibility to anthropogenic pressures in general (noise, disturbance, fishery practices and pollution) adds value to their role as important bio-indicators to determine the general 'health' of the marine ecosystem. Value that can be found not only through the economic worth of the whale and dolphin watching industries but also simply the existence value of having cetaceans around for future generations. Aesthetic and intrinsic values are well understood in concept, albeit difficult to quantify and put into operation. Aesthetic value, in particular, can be of critical importance, because it resonate with the interests of environmental groups and organizations, the media, and a large part of the population. For centuries these charismatic species have inspired the hearts of the general public and could be considered the most popular of all wildlife taxa. Conservation initiatives that build upon cetaceans as 'flagship species' are therefore potentially able to receive significant political and public attention and support. Overall, because of their educational, scientific and economic value, as well as the great need for a large conservation area, cetaceans have a vital role in protecting ocean habitats and bringing large new areas under conservation management.

This paper has also examined research gaps, questions and issues (e.g., population abundance estimates, as well as the biological, ecological, physiological characteristics) surrounding cetacean species in the context of biodiversity conservation and highlighted the need of targeted conservation management actions to reduce the impacts of key threatening processes in the Mediterranean Sea. These animals are highly mobile and cover wide stretches of the Mediterranean Sea across a variety of habitats with the potential to effectively summarize the evolution of contaminants in its ecosystems. All the identified threats-often derived from multiple rather than singular sources, with different courses of action each raising potential risks-are interlinked and cumulatively contribute to the habitat degradation of the entire area as well as reduced health status of the cetaceans that live there. Given the extensive list of threats and in the face of scientific uncertainty the 'precautionary principle' must be adopted at all levels in attempts to mitigate impacts and thus provides scope for the translation of the principle into operational measures. Nevertheless, determining which specific management approaches or tools should be considered precautionary is not straightforward. For instance, environmental impact assessment/risk assessment, ecosystem-based management approaches in MPA, and adaptive management all provide tools or tactics for addressing and managing uncertainty regarding cetaceans. However, while each can be implemented in a precautionary fashion, they do not necessarily translate to precautionary management.

In conclusion, this paper has outlined not only the complexities and challenges we face in ensuring a sustainable future for cetaceans, but it has also detailed the great opportunities which are available through further research, united conservation management approaches and the international development of a sustainable future for cetaceans. The practical implications of these discussions are to recognize that human activities are having dramatic impacts and wipe out individuals, species or even functional and structural categories of organisms. Species and habitats loss together with ecosystem degradation occur too fast for evolutionary adjustment, demanding immediate proactive social changes. This is not the domain of scientists, managers or of conservationists alone, but of all humans. Natural entities have intrinsic value in virtue of their independence from human design and control. We should recognize that cetaceans have value in themselves.

\section{References}

1. Coll M, Piroddi C, Steenbeek J, Kaschner K, Ben Rais Lasram F, et al. (2010) The biodiversity of the Mediterranean Sea: estimates, patterns, and threats. PLoS One 5: e11842.

2. Lejeusne C, Chevaldonné P, Pergent-Martini C, Boudouresque CF, Pérez $\mathrm{T}$ (2010) Climate change effects on a miniature ocean: the highly diverse, highly impacted Mediterranean Sea. Trends Ecol Evol 25: 250-260.

3. Liquete C, Piroddi C, Drakou EG, Gurney L, Katsanevakis S, et al. (2013) Current status and future prospects for the assessment of marine and coastal ecosystem services: a systematic review. PLoS One 8: e67737.

4. Halpern BS, Walbridge S, Selkoe KA, Kappel CV, Micheli F, et al. (2008) A global map of human impact on marine ecosystems. Science 319: 948-952.

5. Costello MJ, Coll M, Danovaro R, Halpin P, Ojaveer H, et al. (2010) A census of marine biodiversity knowledge, resources, and future challenges. PLoS One 5: e12110.

6. Mouillot D, Albouy C, Guilhaumon F, Ben Rais Lasram F, Coll M, et al. (2011) Protected and threatened components of fish biodiversity in the Mediterranean sea. Curr Biol 21: 1044-1050.

7. Micheli F, Halpern BS, Walbridge S, Ciriaco S, Ferretti F, et al. (2013) Cumulative human impacts on Mediterranean and Black Sea marine ecosystems: assessing current pressures and opportunities. PLoS One 8: e79889.

8. Zenetos A, Gofas S, Morri C, Rosso A, Violanti D, et al. (2012) Alien species in the Mediterranean Sea by 2012. A contribution to the application of European Union's Marine Strategy Framework Directive (MSFD). Part 2. Introduction trends and pathways. Mediterr Mar Sci 13: 328-352.

9. Katsanevakis S, Zenetos A, Belchior C, Cardoso AC (2013) Invading European Seas: assessing pathways of introduction of marine aliens. Ocean Coast Manag 76: 64-74.

10. Katona S, Whitehead H (1988) Are cetacean ecologically important? Oceanogr Mar Biol Annu Rev 26: 553-568.

11. Bowen WD (1997) Role of marine mammals in aquatic ecosystems. Mar Ecol Prog Ser 158: 267-274.

12. Sergio F, Caro T, Brown D, Clucas B, Hunter J, et al. (2008) Top predators as conservation tools: ecological rationale, assumptions, and efficacy. Ann Rev Ecol Evol Syst 39: 1-19.

13. IOC (2001) The strategic plan for the Health of the Ocean Panel for GOOS. IOC (Intergovernmental Oceanographic Commission), United Nations Educational, Scientific and Cultural Organization, Paris.

14. Moore SE (2008) Marine mammals as ecosystem sentinels. J Mammal 89: 534-540.

15. UNEP-MAP RAC/SPA (2010) The Mediterranean Sea Biodiversity: State of the ecosystems, pressures, impacts and future priorities.

16. Godard-Codding CAJ, Clark R, Fossi MC, Marsili L, et al. (2011) Pacific Ocean-wide profile of CYP1A1 expression, stable carbon and nitrogen isotope ratios, and organic contaminant burden in sperm whale skin biopsies. Environ Health Perspect 119: 337-343.

17. ACCOBAMS (2014) Impact of Climate Change on Cetaceans of the Mediterranean and Black Seas. Report of the ACCOBAMS expert workshop.

18. Hoyt E (2011) Marine Protected Areas for Whales, Dolphins and Porpoises: A world handbook for cetacean habitat conservation and planning. Earthscan/Taylor \& Francis, London and New York.

19. Parsons ECM, Baulch S, Bechshoft T, Bellazzi G, Bouchet P, et al (2015) Key research questions of global importance for cetacean conservation. Endang Species Res 27: 113-118.

20. Sandler R (2012) Intrinsic Value, Ecology, and Conservation. Nature Educational Knowledge 3: 4 .

21. Soulé ME (1985) What is conservation biology? Bioscience 35: 727-734. 
22. United Nations (1992a) Rio Declaration on Environment and Development.

23. United Nations (1992b) Convention on Biological Diversity.

24. Parsons ECM, Warburton CA, Woods-Ballard A, Hughes A, Johnston P (2003) The value of conserving whales: The impacts of cetacean-related tourism on the economy of rural West Scotland', Aquatic Conservation: Marine and Freshwater Ecosystems 13: 397-415.

25. O'Connor S, Campbell R, Cortez H, Knowles T (2009) Whale Watching Worldwide: tourism numbers, expenditures and expanding economic benefits, a special report from the International Fund for Animal Welfare. Yarmouth MA, USA, prepared by Economists at Large.

26. Navarro J, Coll M, Cardador L, Fernandez AM, Bellido JM (2015) The relative roles of the environment, human activities and spatial factors in the spatial distribution of marine biodiversity in the Western Mediterranean Sea. Prog Oceanogr 131: 126-137.

27. Reeves R, Notarbartolo di Sciara G (2006) The status and distribution of cetaceans in the Black Sea and Mediterranean Sea. IUCN Centre for Mediterranean Cooperation, Malaga, Spain.

28. Notarbartolo di Sciara G, Birkun A Jr (2010) Conserving whales, dolphins and porpoises in the Mediterranean and Black Seas: an ACCOBAMS status report. ACCOBAMS, Monaco.

29. IUCN (2012) Marine Mammals and Sea Turtles of the Mediterranean and Black Seas. Gland, Switzerland and Malaga, Spain.

30. Forcada J (2009) Distribution In: (2ndedn) Perrin WF, Wursig B and Thewissen JGM (Eds), Encyclopedia of marine mammals, Elsevier, Inc., San Diego, California, 602-608.

31. WWF/IUCN (2004) The Mediterranean deep-sea ecosystems: an overview of their diversity, structure, functioning and anthropogenic impacts, with a proposal for conservation. IUCN, Málaga and WWF, Rome.

32. Würtz M (2010) Mediterranean Pelagic Habitat: Oceano graphic and Biological Processes, An Overview. Gland, Switzerland and Malaga, Spain: IUCN.

33. Mussi B, Miragliuolo A (2003) I cetacei della costa nord occidentale dell'isola d'Ischia (Canyon di Cuma). In Ambiente marino e costiero e territorio delle isole Flegree (Ischia, Procida e Vivara-Golfo di Napoli). Risultati di uno studio multidisciplinare. Gambi MC, De Lauro M, Jannuzzi F (eds). Liguori Editore 213-232.

34. Pace DS, Miragliuolo A, Mussi B (2012) The case study of the marine Canyon of Cuma (Tyrrhenian Sea, Italy): implication for cetacean conservation off Ischia Island. In Würtz $M$ (ed.) Mediterranean submarine canyon. Ecology and governance. IUCN, Gland, Switzerland, 89-97.

35. Bearzi G, Politi E, Agazzi S, Bruno S, Costa M, et al. (2005) The decline of short-beaked common dolphins Delphinus delphis in Eastern Ionian Sea coastal waters. In: Stockin K, Vella A and Evans PGH (Eds) Proceedings of the Workshop Common dolphins: current research threats and issues. European Cetacean Society Newsletter Special Issue 45.

36. Mussi B, Miragliuolo A, Zucchini A, Pace DS (2014) Occurence and spatio-temporal distribution of sperm whale (Physeter macrocephalus) in the submarine canyon of Cuma (Tyrrhenian Sea, Italy). Aquatic Conserv: Mar Freshw Ecosyst 24: 59-70.

37. Pace DS, Miragliuolo A, Mariani M, Vivaldi C, Mussi B (2014) Sociality of sperm whales (Physeter macrocephalus) off Ischia island (Tyrrhenian Sea, Italy). Aquatic Conserv: Mar Freshw Ecosyst 24: 71-82.

38. Scalise S, Moulins A, Rosso M, Corsi A, Wurtz M (2005) First results on Cuvier's beaked whale distribution in the Ligurian Sea related to depth and depth gradient. Abstracts of the 34th Annual Symposium of the European Association for Aquatic Mammals. Riccione, Italy.

39. Tepsich P, Rosso M, Halpin PN, Moulins A (2014) Habitat preferences of two deep-diving cetacean species in the northern Ligurian Sea. Mar Ecol Prog Ser 508: 247-260.

40. Fiori C, Alessi J, Mandich A, Paoli C, Vassallo P (2015) Assessment of Tyrrhenian Seamounts attractiveness on Stenella coeruleoalba. Biol Mar Mediterr 22: 220-221.
41. Cañadas AM, Sagarminaga R, Garcia-Tiscar S (2002) Cetacean distribution related with depth and slope in the Mediterranean waters off southern Spain. Deep Sea Res. Part I, 49: 2053-2073.

42. David L (2000) Rôle et importance des canyons sous-marins dans le talus continental sur la distribution des cétacés en période estivale en Méditerranée nord-occidentale. PhD thèse, Ecole pratique des hautes études, Montpellier, France.

43. Frantzis A (1998) Does acoustic testing strand whales? Nature 392: 29.

44. Lewis T, Matthews J, Boisseau O, Danbolt M, Gillespie D, et al. (2013) 6th International Workshop on Detection, Classification, Localization, \& Density Estimation of Marine Mammals using Passive Acoustics. St Andrews, UK.

45. Natoli A, Birkun A, Aguilar A, Lopez A, Hoelzel AR (2005) Habitat structure and the dispersal of male and female bottlenose dolphins (Tursiops truncatus). Proc Biol Sci 272: 1217-1226.

46. Gaspari S, Scheinin A, Holcer D, Fortuna C, Natali C, et al. (2015) Drivers of Population Structure of the Bottlenose Dolphin (Tursiops truncatus) in the Eastern Mediterranean Sea. Evol Biol 42: 177-190.

47. Garcia Martinez J, Moya A, Raga JA, Latorre A (1999) Genetic differentiation in the striped dolphin Stenella coeruleoalba from European waters according to mitochondrial DNA (mtDNA) restriction analysis. Molec Ecol 8: 1069-1073.

48. Aguilar A, Gaspari S (2010) Striped dolphin, Stenella coeruleoalba Mediterranean subpopulation. Assessment submitted to the IUCN Red List.

49. Calzada N, Aguilar A (1995) Geographical variation of body size in Western Mediterranean striped dolphins (Stenella coeruleoalba). Z Saugetierkd 60: 257-264.

50. Monaci F, Borrel A, Leonzio C, Marsili L, Calzada N (1998) Trace elements in striped dolphins (Stenella coeruleoalba) from the western Mediterranean. Environ Pollut 99: 61-68.

51. Gaspari S, Airoldi S, Hoelzel AR (2007) Risso's dolphins (Grampus griseus) in UK waters is differentiated from a population in the Mediterranean Sea and genetically less diverse. Conservat Genet 8: 727-732.

52. Natoli A, Canadas A, Vaquero C, Politi E, Fernandez-Navarro P, et al. (2008) Conservation genetics of the short beaked common dolphin (Delphinus delphis) in the Mediterranean Sea and in the eastern North Atlantic Ocean. Conserv Genet 9: 1479-1487.

53. Dalebout ML, Robertson KM, Frantzis A, Engelhaupt D, Mignucci AA, et al. (2005) Worldwide structure of mtDNA diversity among Cuvier's beaked whales (Ziphius cavirostris): implications for threatened populations. Molec Ecol 14: 3353-3371.

54. Bérubé M, Aguilar A, Dendanto D, Larsen F, Notarbartolo di Sciara G, et al. (1998) Population genetic structure of North Atlantic, Mediterranean Sea and Sea of Cortez fin whales, Balaenoptera physalus (Linnaeus 1758): analysis of mitochondrial and nuclear loci. Mol Ecol 7: 585-599.

55. Palsboll PJ, Berube M, Aguilar A, Notarbartolo di Sciara G, Nielsen R (2004) Discerning between recurrent gene flow and recent divergence under a finite-site mutation model applied to North Atlantic and Mediterranean Sea fin whale (Balaenoptera physalus) populations. Evolution 58: 670-675.

56. Drouot V, Bérubé M, Gannier A, Goold JC, Reid RJ, Palsbøll PJ (2004) A note on genetic isolation of Mediterranean sperm whales (Physeter macrocephalus) suggested by mitochondrial DNA. J Cet Res Manag 6: 29-32.

57. Engelhaupt D (2004) Molecular ecology of the sperm whale in the Gulf of Mexico, Mediterranean Sea and North Atlantic. Ph.D. Thesis, Durham University, UK.

58. UNEP (1996) State of the Marine and Coastal Environment in the Mediterranean Region. MAP Technical Report Series No. 100. UNEP, Athens.

59. Shaltout M, Omstedt A (2014) Recent sea surface temperature trends and future scenarios for the Mediterranean Sea. Oceanologia 56: 411-443. 
60. Blue Plan (2008) The Blue Plan's Sustainable Development Outlook for the Mediterranean. UNEP Blue Plan Activity Centre, Sophia Antipolis, France.

61. Simmonds M, Nunny L (2002) Cetacean habitat loss and degradation in the Mediterranean Sea. In: G. Notarbartolo di Sciara (Ed.), Cetaceans of the Mediterranean and Black Seas: state of knowledge and conservation strategies. A report to the ACCOBAMS Secretariat, Section 7.

62. Cuttelod A, Garcia N, Abdul Malak D, Temple H, Katariya V (2008) The Mediterranean: a biodiversity hotspot under threat. In: Vié JC, HiltonTaylor Cand Stuart SN (Eds) The 2008 Review of The IUCN Red List of Threatened Species, IUCN Gland, Switzerland.

63. UNEP-MAP-RAC/SPA (2013) Important areas for the conservation of cetaceans in the Gulf of Lions shelf and slope area: synthesis of existing data on cetaceans and threats. By David, L., DiMéglio, N. Ed. RAC/SPA, Tunis.

64. Fossi MC, Marsili L (2011) Multi-Trial Eco toxicological Diagnostic Tool. In Uday Khopkar (Ed.), Cetacean Skin Biopsies, Skin BiopsyPerspectives, InTech.

65. Mazzariol S, Di Guardo G, Petrella A, Marsili L, Fossi CM, et al. (2011) Sometimes sperm whales (Physeter macrocephalus) cannot find their way back to the high seas: a multidisciplinary study on a mass stranding. PLoS One 6: e19417.

66. Franzosini C, Genov T, Tempesta M (2013) Cetacean manual for MPA managers. ACCOBAMS, MedPAN and UNEP/MAP-RAC/SPA (Ed.) RAC/SPA, Tunis.

67. Kemp NJ (1996) Habitat Loss and Degradation. In Simmonds MP and Hutchinson JD (Eds.). The Conservation of Whales and Dolphins, John Wiley \& Sons Ltd, Chichester.

68. IPCC (2007) Climate changes: synthesis report. Contribution of working groups I-III to the Fourth assessment report of the Intergovernmental panel on climate change Cambridge Univ. Press, Cambridge.

69. Lionello P, Gacic M, Gomis D, Garcia-Herrera R, Giorgi F, et al. (2010) Program focuses on climate of the Mediterranean region EOS T. Am Geophys Un 93: 105-106.

70. Richardson AJ, McKinnon D, Swadling KM (2009) Zooplankton. In Poloczanska, Hobday and Richardson (Eds), A marine climate change impacts and adaptation report card for Australia 2009, National Climate Change Adaptation Research Facility.

71. Arcangeli A, Azzolin M, Campana I, Castelli A, Giacoma C, et al. (2014) Cetaceans at risk by plastic debris: a protocol for simultaneous monitoring of marine litter and marine mega-fauna. First results from the FLT Mediterranean monitoring network. Biol Mar Mediterr 22: 218-219.

72. Nøttestad L, Krafft BA, Anthonypillai V, Bernasconi M, Langard L, et al. (2015) Recent changes in distribution and relative abundance of cetaceans in the Norwegian Sea and their relationship with potential prey. Front Ecol Evol 2: 1-11.

73. Simmonds M, Gambaiani D, Notarbartolo di Sciara G (2012) Climate change effects on Mediterranean Cetaceans: Time for action. In Stambler N (Ed), Life in the Mediterranean Sea: a look at Climate Change. Nova Science Publishers, Inc. 685-701.

74. Sabine CL, Feely RA, Gruber N, Key RM, Lee K, et al. (2004) The oceanic sink for anthropogenic CO2. Science 305: 367-371.

75. Howard WR, Nash M, Anthony K, Schmutter K, Bostock H, et al. (2012) Ocean acidification. In Poloczanska ES, Hobday AJ and Richardson AJ (Eds) A Marine Climate Change Impacts and Adaptation Report Card for Australia.

76. Bentaleb I, Martin C, Mate B, Mayzaud P, Siret D, et al. (2011) Foraging shift of Mediterranean fin whales in a changing environment elucidated by satellite tracking and baleen plate stable isotopes. Mar Ecol Prog Ser 438: 285-302.

77. Hoffman JR, Fonseca A, Drews C (2009) Cetaceans and Other Marine Biodiversity of the Eastern Tropical Pacific: Options for Adapting to Climate Change. Report from the Workshop MINAET/WWF/ EcoAdapt/CI/IFAW/TNC/WDCS/IAI/PROMAR, San Jose, Costa Rica.

78. Bearzi G (2002) Interactions between cetacean and fisheries in the Mediterranean Sea. In: Notarbartolo di Sciara G (Ed), Cetaceans of the
Mediterranean and Black Seas: state of knowledge and conservation strategies. A report to the ACCOBAMS Secretariat, Monaco, February 2002. Section 9.

79. Karpouzli E, Leaper R (2004) Opportunistic observations of interactions between sperm whales and deep-water trawlers based on sightings from fisheries observers in the northwest Atlantic. Aquat Conserv Mar Freshw Ecosyst. 14: 95-103.

80. Fertl D, Leatherwood S (1997) Cetacean interactions with trawls: a preliminary review. J Northwest Atl Fish Sci. 22: 219-248.

81. Díaz López B, Shirai BJA (2008) Marine aquaculture and bottlenose dolphins' (Tursiops truncatus) social structure. Behav Ecol Sociobiol 62: 887-894.

82. Pace DS, Pulcini M, Triossi F (2011) Anthropogenic food patches and association patterns of Tursiops truncatus at Lampedusa Island, Italy. Behav Ecol 23: 254-264.

83. Reeves RR, Read AJ, Notarbartolo di Sciara G (2001) Report of the Workshop on Interactions between Dolphins and Fisheries in the Mediterranean: Evaluation of Mitigation Alternatives. ICRAM Workshop. Doc. SC/53/SM3 presented at the Meeting of the International Whaling Commission.

84. Bearzi G, Agazzi S, Gonzalvo J, Bonizzoni S, Costa M, et al. (2010) Biomass removal by dolphins and fisheries in a Mediterranean Sea coastal area: do dolphins have an ecological impact on fisheries? Aquat Conserv Mar Freshw Ecosyst 20: 549-559.

85. Lauriano G, Fortuna CM, Moltedo G, Notarbartolo Di Sciara G (2004) Interactions between common bottlenose dolphins (Tursiops truncatus) and the artisanal fishery in Asinara Island National Park (Sardinia): assessment of catch damage and economic loss. J Cetacean Res Manage 6: 165-173.

86. Díaz López, B (2006) Interactions between Mediterranean bottlenose dolphins (Tursiops truncatus) and gillnets off Sardinia, Italy. ICES J Mar Sci 63: 946-951.

87. Fossa F, Lammers MO, Orsi Relini L (2012) Measuring interactions between common bottlenose dolphin (Tursiops truncatus) and artisanal fisheries in the Ligurian Sea. Europ Res Cet XXVI.

88. Gonzalvo J, Valls M, Cardona L, Aguilar A (2008) Factors determining the interaction between common bottlenose dolphins and bottom trawlers off the Balearic Archipelago (Western Mediterranean Sea). J Experimental Mar Biol Ecol 367: 47-52.

89. Gazo M, Gonzalvo J, Aguilar A (2008) Pingers as deterrents of bottlenose dolphins interacting with trammel nets. Fish Res 92: 70-75.

90. Bearzi G, Bonizzoni S, Gonzalvo J (2011) Dolphins and coastal fisheries within a marine protected area: mismatch between dolphin occurrence and reported depredation. Aquatic Conserv: Mar Freshw Ecosyst 21: 261-267.

91. Di Natale A, Notarbartolo di Sciara G (1994) A review of the passive fishing nets and trap fisheries in the Mediterranean Sea and of cetacean bycatch. Report of Int Whal Commn, Special Issue 15: 189-202.

92. Brotons JM, Munilla Z, Grau A, Rendell L (2008) Do pingers reduce interactions between bottlenose dolphins and nets around the Balearic Islands? Endang Species Res 5: 301-308.

93. Tudela S (2004) Ecosystem effects of fishing in the Mediterranean: an analysis of the major threats of fishing gear and practices to biodiversity and marine habits. General Fisheries Commission for the Mediterranean (FAO), Stud. Rev. 74, FAO, Rome.

94. Mussi B, Miragliuolo A, Pace DS (2005) Nets and loopholes: the continued use of driftnets by the Italian Fleet. FINS 2: 5-7.

95. EJF (2007) Illegal Driftnetting in the Mediterranean, Environmental Justice Foundation, London, UK. ISBN No. I- 904523-II-0.

96. Oceana-MarViva (2008) Adrift! Swordfish and driftnets in the Mediterranean Sea. Oceana-MarViva Mediterranean Sea Project.

97. Pace DS, Miragliuolo A, Mussi B (2005) Behaviour of a nursery group of entangled sperm whale (Southern Thyrrennian Sea, Italy). Annual Conference of the European Cetacean Society (ECS), La Rochelle, France, 01-04 April, 2005. In European Research on Cetaceans. 
98. Pace DS, Miragliuolo A, Mussi B (2008) Behaviour of a social unit of sperm whales (Physeter macrocephalus) entangled in a driftnet off Capo Palinuro (Southern Tyrrhenian Sea, Italy). JCRM 10: 131-135.

99. Bearzi G, Agazzi S, Gonzalvo Villegas J, Costa M, Bonizzoni S, et al. (2008) Overfishing and the disappearance of short-beaked common dolphins from western Greece. Endan Species Res 5: 1-12.

100. Bellingeri M, Fossa F, Gnone G (2011) Interaction between Tursiops truncatus and trawlers: different behaviour in two neighbouring areas along the eastern Ligurian Sea. Biol Mar Mediterr 18: 174-175.

101. Gilman E, Brothers N, McPherson G, Dalzell P (2006) A review of cetacean interactions with longline gear. J Cet Res Manag 8: 215-223.

102. Wang J, Yang S (2002) Interactions between Taiwan's distant water longline fleet and cetaceans. In M Donoghue, $\mathrm{R}$ Reeves and G Stone (Eds.) New England Aquarium Forum Series Report. 03-1. Report of the Workshop on Interactions Between Cetaceans and Longline Fisheries, New England Aquarium Press, Boston, 3-4.

103. Di Natale A (1992) A impact of fisheries on cetaceans in the Mediterranean Sea. In Evans PGH (Ed) European Research on Cetaceans 6:18.

104. Duguy R, Besson J, Cassinos A, Di Natale A, Filella S, et al. (1983) L'impact des activités humaines sur les cétacés de la Méditerranée occidentale. Rapp Comm Int Mer Médit 28: 219-222

105. Macías López D, García Barcelona S, Báez JC, de la Serna JM, Ortiz de Urbina JM (2012) Marine mammal bycatch in Spanish Mediterranean large pelagic longline fisheries, with a focus on Risso's dolphin (Grampus griseus). Aquat Living Resour 25: 321-331.

106. Mussi B, Gabriele R, Miragliuolo A, Battaglia M (1998) Cetacean sightings and interactions with fisheries in the archipelago Pontino Campano, southern Tyrrhenian Sea, 1991-1995. Eur Res Cetaceans 12: 63-65.

107. Tudela S (2004) Ecosystem effects of fishing in the Mediterranean: an analysis of the major threats of fishing gear and practices to biodiversity and marine habitats. Studies and reviews. General Fisheries Commission for the Mediterranean 74: 1-44.

108. University of Barcelona (1995) A survey of interactions between marine mammals and fisheries in the south western waters of the EEC (SUROESTE). Final Report to the General Directorate for Fisheries, EC DGXIV. Project PEM/92/3507.

109. Hall M, Roman M (2013) Bycatch and non-tuna catch in the tropical tuna purse seine fisheries of the world. FAO Fisheries and Aquaculture Technical Paper No. 568, Rome.

110. Vella A (2002) La pesca del Tonno rosso del Mediterraneo centromeridionale, nell'area delle Isole Maltesi. Conferenza Internazionale sulla pesca Mediterranea. Napoli, Italia.

111. Scarpato D, Simeone M (2005) La filiera del tonno rosso Mediterraneo: problematiche e prospettive del comparto in Campania. Università degli Studi di Napoli "Parthenope" Istituto di Studi Economici. Working Paper n. 42005.

112. Miyake PM, De la Serna JM, Di Natale A, Farrugia A, Katavic I, et al. (2003) General review of Atlantic bluefin tuna farming in the Mediterranean area. ICCAT Collective Volume of Scientific Papers 55 114-124.

113. Alemany F, Quintanilla L, Velez-Belchí P, García A, Cortés D, et al. (2010) Characterization of the spawning habitat of Atlantic bluefin tuna and related species in the Balearic Sea (western Mediterranean). Progr Oceanog 86: 21-38.

114. Magnaghi L, Podestà M (1987) An accidental catch of 8 striped dolphins, Stenella coeruleoalba (Meyen 1833), in the Ligurian Sea (Cetacea Delphinidae). Atti Società Italiana di Scienze Naturali, Museo Civico di Soria Naturale, Milano, 1283-4: 235-239.

115. FAO (2014) The state of world fisheries and aquaculture. FAO Fisheries and Aquaculture Department. Food and agriculture organization of the United Nations, Rome, Italy.

116. Díaz López B (2012) Bottlenose dolphins and aquaculture: interaction and site fidelity on the northeastern coast of Sardinia (Italy). Mar Biol 159: 2161-2172.
117. Díaz López B, Shirai BJA (2007) Bottlenose dolphin (Tursiops truncatus) presence and incidental capture in a marine fish farm on the northeastern coast of Sardinia (Italy). JMBA 87: 113-117.

118. Watson-Capps JJ, Mann J (2005) The effects of aquaculture on bottlenose dolphin (Tursiops sp.) ranging in Shark Bay, Western Australia. Biol Conserv 124: 519-526.

119. Díaz López B, Mariño F (2011) A trial of an acoustic harassment device efficacy on free-ranging bottlenose dolphins in Sardinia, Italy. Mar Freshw Behav Phys 44(4): 197-208.

120. Young NM and Iudicello S (2007) Worldwide Bycatch of Cetaceans. U.S. Dep. Commerce, NOAA Tech. Memo, NMFS-OPR-36.

121. IWC (International Whaling Commission) (1994) Report of the workshop on mortality of cetaceans in passive fishing nets and traps. Rep Int Whal Commn 15: 1-72.

122. Silvani L, Gazo M and Aguilar A (1999) Spanish driftnet fishing and incidental catches in the western Mediterranean. Biological Conservation 90: 79-85.

123. Silvani L, Raich J, Aguilar A (1992) Bottlenose dolphins, Tursiops truncatus, interacting with fisheries in the Balearic Islands, Spain. Europ Res on Cet 6: 32-34.

124. UNEP/IUCN (1994) Technical report on the state of cetaceans in the Mediterranean. Mediterranean Action Plan Technical Reports Series No. 82, United Nations Environment Programme (UNEP), Regional Activity Centre for Specially Protected Areas, Tunis.

125. Imbert G, Gaertner JC, Laubier L (2001) Prevention a l'aide de repulsifs acoustiques des captures de dauphins par les thonailles. Conference International sur les cetaces Mediterranee de la RIMMO.

126. Reeves RR, Berggren P, Crespo EA, Gales N, Northridge SP, et al. (2005) Global Priorities for Reduction of Cetacean Bycatch. World Wildlife Fund.

127. Pauly D, Christensen V, Guénette S, Pitcher TJ, Sumaila UR, et al. (2002) Towards sustainability in world fisheries. Nature 418: 689-695.

128. Swartz W, Sala E, Tracey S, Watson R, Pauly D (2010) The spatial expansion and ecological footprint of fisheries (1950 to present). PLoS One 5: e15143.

129. Pauly D, Christensen VV, Dalsgaard J, Froese R, Torres F Jr (1998) Fishing down marine food webs Science 279: 860-863.

130. Pauly D, Watson R (2005) Background and interpretation of the 'Marine Trophic Index' as a measure of biodiversity. Philos Trans R Soc Lond B Biol Sci 360: 415-423.

131. Etnier MA, Fowler CW (2005) Comparison of Size Selectivity Between Marine Mammals and Commercial Fisheries with Recommendations for Restructuring Management Policies. NOAA Technical Memorandum.

132. Conover DO, Munch SB (2002) Sustaining fisheries yields over evolutionary time scales. Science 297: 94-96.

133. Palomera I, Olivar MP, Salat J, Sabat A, Coll M, et al. (2007) Small pelagic fish in the NW Mediterranean Sea: An ecological review. Prog Oceanog 74: $377-396$.

134. MacKenzie BR, Mosegaard H, Rosenberg AA (2009) Impending collapse of Bluefin tuna in the northeast Atlantic and Mediterranean. Conservat Lett 2: 26-35.

135. Lascelles B, Notarbartolo di Sciara G, Agardi T, Cuttelod A, Eckert S, et al. (2014) Migratory marine species: their status, threats and conservation management needs. Aquatic Conserv: Mar Freshw Ecosyst 24: 111-127.

136. Cavanagh RD, Gibson C (2007) Overview of the conservation status of cartilaginous fishes (Chondrichthyans) in the Mediterranean Sea. IUCN, Gland, Switzerland and Malaga, Spain.

137. Bearzi G, Politi E, Agazzi S, Azzellino A (2006) Prey depletion caused by overfishing and the decline of marine megafauna in eastern Ionian Sea coastal waters (central Mediterranean). Biol Conserv 127: 373-382.

138. Bearzi G, Fortuna CM, Reeves RR (2008) Ecology and conservation of common bottlenose dolphins Tursiops truncatus in the Mediterranean Sea. Mammal Rev 39: 92-123. 
139. Campana I, Crosti R, Angeletti D, Carosso L, David L, et al. (2015) Cetacean response to summer maritime traffic in the Western Mediterranean Sea. Mar Environ Res 109: 1-8.

140. Jahoda M, Lafortuna CL, Biassoni N, Almirante C, Azzellino A, et al. (2003) Mediterranean fin whale's (Balaenoptera physalus) response to small vessels and biopsy sampling assessed through passive tracking and timing of respiration. Mar Mammal Sci 19: 96-110.

141. Castellote M, Clark CW, Lammers M (2012) Acoustic and behavioural changes by fin whales (Balaenoptera physalus) in response to shipping and airgun noise. Biol Conserv 147: 115-122.

142. Papale E, Azzolin M, Giacoma C (2012) Vessel traffic affects bottlenose dolphin (Tursiops truncatus) behaviour in waters surrounding Lampedusa Island, south Italy. JMBA 92: 1877-1885.

143. La Manna G, Manghi M, Pavan G, Lo Mascolo F, Sara G (2013) Behavioural strategy of common bottlenose dolphins (Tursiops truncatus) in response to different kinds of boats in the waters of Lampedusa Island (Italy). Aquatic Conserv: Mar Freshw Ecosyst 23: 745-757.

144. Pirotta E, Merchant ND, Thompson PM, Barton TR, Lusseau D (2015) Quantifying the effect of boat disturbance on bottlenose dolphin foraging activity. Biol Conserv 181: 82-89.

145. Aguilar Soto N, Johnson M, Madsen PT, Tyack PL, Bocconcelli A, et al. (2006) Does intense ship noise disrupt foraging in deep-diving Cuvier's beaked whale (Ziphius cavirostris)? Mar Mammal Sci 22: 690-699.

146. Tyack PL, Zimmer WM, Moretti D, Southall BL, Claridge DE, et al. (2011) Beaked whales respond to simulated and actual navy sonar. PLoS One 6: e17009.

147. Arcangeli A, Orasi A, Carcassi SP, Crosti R (2014) Exploring thermal and trophic preference of Balaenoptera physalus in the central Tyrrhenian Sea: a new summer feeding ground? Mar Biol 161: 427-436.

148. Geijer CK, Jones PJ (2015) A network approach to migratory whale conservation: are MPAs the way forward or do all roads lead to the IMO? Mar Policy 51: 1-12.

149. Vaes TJ, Druon N (2013) Mapping of potential risk of ship strike with fin whales in the Western Mediterranean Sea. Report of the Joint Research Centre of the European Commission.

150. ACCOBAMS (2013) Resolution 5.11 Ship strikes on cetaceans in the Mediterranean Sea.

151. Panigada S, Pesante G, Zanardelli M, Capoulade F, Gannier A, et al. (2006) Mediterranean fin whales at risk from fatal ship strikes. Mar Pollut Bull 52: 1287-1298.

152. Notarbartolo di Sciara G (2014) Sperm whales, Physeter macrocephalus, in the Mediterranean Sea: a summary of status, threats, and conservation recommendations. Aquatic Conserv: Mar Freshw Ecosyst 24: 4-10.

153. Ritter F (2012) Collisions of sailing vessels with cetaceans worldwide: first insights into a seemingly growing problem. J Cet Res Manag 12: 119-127.

154. Souffleurs d'Ecume (2012) Collisions between vessels and large cetaceans in the Pelagos Sanctuary. Souffleurs d'Ecume Report.

155. Laist DW, Knowlton AR, Mead JG, Collet AS, Podesta M (2001) Collisions between ships and whales. Mar Mammal Sci 17: 35-75.

156. Silber GK, Slutsky J, Bettridge S (2010) Hydrodynamics of a ship/whale collision. J Exp Mar Biol Ecol 391: 10-19.

157. Gambaiani D, Mayol P, Capoulade F, Mckenzie C, Mckenzie E, et al. (2010) Impact du trafic maritime sur les cétacés. Synthèse des connaissances sur limpact du trafic maritime 1:25-88.

158. IWC (International Whaling Commission) (2007) Ship strikes working group, Second progress report to the conservation committee. Paper IWC/59/CC3 presented to the Annual Meeting of the International Whaling Commission.

159. Parsons ECM (2012b) From whaling to whale watching: a history of cetaceans in Scotland. Glasgow Naturalist 25: 53-57.

160. Bejder L, Samuels A, Whitehead H, Gales N (2006) Interpreting shortterm behavioural responses within a longitudinal perspective. Anim Behav 72: 1149-1158.
161. Orams MB (2004) Why dolphins may get ulcers: considering the impacts of cetacean-based tourism in New Zealand. Tourism Mar Environ 1: 17-28.

162. Williams R, Lusseau D, Hammond PS (2006) Estimating relative energetic costs of human disturbance to killer whales (Orcinus orca). Biol Conserv 133: 301-311.

163. Stockin KA, Lusseau D, Binedell V, Wiseman N, Orams MB (2008) Tourism affects the behavioural budget of the common dolphin Delphinus sp. in the Hauraki Gulf, New Zealand. Mar Ecol Prog Ser 355: 287-295.

164. Carrera ML, Favaro EGP, Souto A (2008) The response of marine tucuxis (Sotalia fluviatilis) towards tourist boats involves avoidance behaviour and a reduction in foraging. Anim Welf 17: 117-123.

165. Arcangeli A, Crosti R (2009) The short-term impact of dolphin-watching on the behaviour of bottlenose dolphins (Tursiops truncatus) in Western Australia. J Mar Anim Ecol 2: 3-9.

166. Visser F, Hartman KL, Rood EJJ, Hendriks AJE, Zult DB, et al. (2011) Risso's dolphins alter daily resting pattern in response to whale watching at the Azores. Mar Mammal Sci 27: 366-381.

167. Jensen FH, Wahlberg M, Bejder L, Madsen P (2008) Noise levels and masking potential of small whale watching and research vessel around two delphinid species. Bioacoustics 17: 166-168.

168. Miragliuolo A, Mussi B, Bearzi G (2004) Risso's dolphin harassment by pleasure boaters off the Island of Ischia, Central Mediterranean Sea. Europ Res Cet 15: 168-171.

169. Kachel MJ (2008) Threats to the Marine Environment: Pollution and Physical Damage. In: Particularly Sensitive Sea Areas. The IMO's Role in Protecting Vulnerable Marine Areas. Kachel MJ (ed). Springer-Verlag, Berlin, Germany. pp 23-36.

170. GESAMP (1993) Impact of Oil and Related Chemicals and Wastes on the Marine Environment, GESAMP Report and Studies No. 50, IMO Publication, London.

171. Kletou D, Hall-Spencer JM (2012) Threats to Ultraoligotrophic Marine Ecosystems, Marine Ecosystems, Dr. Antonio Cruzado (Ed.), ISBN: 978-953-51-0176-5, InTech.

172. Pinzone M, Budzinski H, Tasciotti A, Ody D, Lepoint G, et al. (2015) POPs in free-ranging pilot whales, sperm whales and fin whales from the Mediterranean Sea: Influence of biological and ecological factors. Environ Res 142: 185-196.

173. Fossi MC, Casini S, Maltese S, Panti C, Spinsanti G, et al. (2014) An "ex vivo" model to evaluate toxicological responses to mixtures of contaminants in cetaceans: integumentum biopsy slices. Environ Toxicol 29: $1107-1121$

174. Hammond JA, Hall AJ, Dyrynda EA (2005) Comparison of polychlorinated biphenyl (PCB) induced effects on innate immune functions in harbour and grey seals. Aquat Toxicol 74: 126-138.

175. Ross PS, De Swart RL, Reijnders PJ, Van Loveren H, Vos JG, et al. (1995) Contaminant-related suppression of delayed-type hypersensitivity and antibody responses in harbor seals fed herring from the Baltic Sea. Environ Health Perspect 103: 162-167.

176. Ross PS, De Swart RL, Reijnders PJ, Van Loveren H, Vos JG, et al. (1995) Contaminant-related suppression of delayed-type hypersensitivity and antibody responses in harbor seals fed herring from the Baltic Sea. Environ Health Perspect 103: 162-167.

177. Aguilar A, Borrell A (1994) Abnormally high polychlorinated biphenyl levels in striped dolphins (Stenella coeruleoalba) affected by the 1990-1992 Mediterranean epizootic. Sci Total Environ 154: 237-247.

178. Fossi MC, Marsili L, Neri G, Natoli A, Politi E, et al. (2003) The use of a non-lethal tool for evaluating toxicological hazard of organochlorine contaminants in Mediterranean cetaceans: new data 10 years after the first paper published in MPB. Mar Pollut Bull 46: 972-982.

179. Marsili L, Maltese S, Coppola D, Carletti L, Mazzariol S, et al. (2014) Ecotoxicological status of seven sperm whales (Physeter macrocephalus) stranded along the Adriatic coast of Southern Italy. Aquatic Conserv: Mar Freshw Ecosyst 24: 103-118. 
180. De Wit CA, Herzke D, Vorkamp K (2010) Brominated flame retardants in the Arctic environment-trends and new candidates. Sci Total Environ 408: 2885-2918.

181. Alaee M, Arias P, Sjödin A, Bergman A (2003) An overview of commercially used brominated flame retardants, their applications, their use patterns in different countries/regions and possible modes of release. Environ Int 29: 683-689.

182. Pettersson A, van Bavel B, Engwall M, Jimenez B (2004) Polybrominated diphenylethers and methoxylated tetrabromodiphenylethers in cetaceans from the Mediterranean Sea. Arch Environ Contam Toxicol 47: 542-550.

183. NRCC (1983) Polycyclic aromatic hydrocarbons in the aquatic environment: formation, sources, fate and effects on aquatic biota. NRC Associate Committee on Scientific Criteria for Environmental Quality, Publication No. NRCC 18981, Ottawa, Ontario.

184. Kot-Wasik A, Dabrowska D, Namiesnik J (2004) Photodegradation and biodegradation study of benzopyrene in different liquid media. J Photoch Photobio A: Chemistry 168: 109-115.

185. Tanabe S, Tatsukawa R (1992) Chemical modernization and vulnerability of cetaceans: increasing toxic threat of organochlorine contaminants. In Walker $\mathrm{CH}$ and Livingstone DR (Eds) Persistent Pollutants in Marine Ecosystems, Pergamon Press Ltd, Oxford, 161-177.

186. Fossi MC, Marsili L, Junin M, Castello H, Lorenzani JA, et al. (1997) Use of nondestructive biomarkers and residue analysis to assess the health status of endangered species of pinnipeds in the southwest Atlantic. Mar Pollut Bull 34: 157-162.

187. Fossi MC, Marsili L (2011) Multi-Trial Ecotoxicological Diagnostic Tool in Cetacean Skin Biopsies. In Skin Biopsy - Perspectives, Khopkar U (Ed.), InTech Europe, Rijeka, Croatia. Pp 317-336.

188. Muir DC, Howard PH (2006) Are there other persistent organic pollutants? A challenge for environmental chemists. Environ Sci Technol 40: 7157-7166.

189. CBD (Convention on Biological Diversity) (2012) Impacts of Marine Debris on Biodiversity: Current Status and Potential Solutions. Montreal, Technical Series 67.

190. Galgani F, Claro F, Depledge M, Fossi C (2014) Monitoring the impact of litter in large vertebrates in the Mediterranean Sea within the European Marine Strategy Framework Directive (MSFD): constraints, specificities and recommendations. Mar Environ Res 100: 3-9.

191. Barnes DK, Galgani F, Thompson RC, Barlaz M (2009) Accumulation and fragmentation of plastic debris in global environments. Philos Trans R Soc Lond B Biol Sci 364: 1985-1998.

192. Derraik GB (2002) The pollution of the marine environment by plastic debris: a review. Marine Pollution Bulletin 44: 842-852.

193. Gregory MR (1996) Plastic "scrubbers" in hand cleansers: a further (and minor) source for marine pollution identified. Marine Pollution Bulletin 32: 867-871.

194. Cheshire AC, Adler E, Barbière J, Cohen Y, Evans S, et al. (2009) UNEP/IOC Guidelines on Survey and Monitoring of Marine Litter. UNEP Regional Seas Reports and Studies, No. 186; IOC Technical Series No. 83.

195. UNEP (2005) Marine Litter, an Analytical Overview.

196. Baulch S, Perry C (2014) Evaluating the impacts of marine debris on cetaceans. Mar Pollut Bull 80: 210-221.

197. Browne MA, Underwood AJ, Chapman MG, Williams R, Thompson RC, et al. (2015) Linking effects of anthropogenic debris to ecological impacts. Proc Biol Sci 282: 20142929.

198. UNEP/MAP (2011) Strategic Action Programme For The Management Of Marine Litter In The Mediterranean. UNEP(DEPI)/MED WG.357/Inf. 4. Meeting of MED POL Focal Points.

199. CIESM (2014) Marine litter in the Mediterranean and Black Seas. CIESM Workshop Monograph $\mathrm{n}^{\circ} 46$. Briand ed, Monaco.

200. Thompson RC, Olsen Y, Mitchell RP, Davis A, Rowland SJ, et al. (2004) Lost at sea: where is all the plastic? Science 304: 838.
201. Lee KW, Shim WJ, Kwon OY, Kang JH (2013) Size-dependent effects of micro polystyrene particles in the marine copepod Tigriopus japonicus. Environ Sci Technol 47: 11278-11283.

202. Rochman CM, Hoh E, Kurobe T, Teh SJ (2013) Ingested plastic transfers hazardous chemicals to fish and induces hepatic stress. Sci Rep 3: 3263.

203. Koelmans AA, Besseling E, Wegner A, Foekema EM (2013) Plastic as a carrier of POPs to aquatic organisms: a model analysis. Environ Sci Technol 47: 7812-7820.

204. Harwani S, Henry RW, Rhee A, Kappes MA, Croll DA, et al. (2011) Legacy and contemporary persistent organic pollutants in North Pacific albatross. Environ Toxicol Chem 30: 2562-2569.

205. Ryan PG, Moore CJ, van Franeker JA, Moloney CL (2009) Monitoring the abundance of plastic debris in the marine environment. Philos Trans R Soc Lond B Biol Sci 364: 1999-2012.

206. Fossi MC, Coppola, D, Baini M, Giannetti M, Guerranti C, et al. (2014) Large filter feeding marine organisms as indicators of microplastic in the pelagic environment: the case studies of the Mediterranean basking shark (Cetorhinus maximus) and fin whale (Balaenoptera physalus). Mar Environ Res 100: 17-24.

207. Abdulla A, Linden O (2008) Maritime traffic effects on biodiversity in the Mediterranean Sea: Review of impacts, priority areas and mitigation measures. Malaga, Spain: IUCN Centre for Mediterranean Cooperation.

208. Weilgart L (2007) A brief review on known effects of noise on marine mammals. Int J Comp Psych 20: 157-168.

209. Hildebrand JA (2005) Impacts of anthropogenic sound. In: Reynolds JE, Perrin WF, Reeves RR, Montgomery S, Ragen TJ (Eds.), Marine Mammal Research: Conservation Beyond Crisis. The Johns Hopkins University Press, Baltimore, Maryland 101-124.

210. Richardson WJ, Greene CRJr, Malme CI, Thomson DH (1995) Marine mammals and noise. Academic Press, New York.

211. NRC (2005) Marine mammal populations and ocean noise: Determining when noise causes biologically significant effects. The National Academies Press, Washington, DC.

212. Southall BL, Bowles AE, Ellison WT, Finneran JJ, Gentry RL, et al. (2007) Marine Mammal Noise Exposure Criteria: Initial Scientific Recommendations. Aquat Mamm 33(4).

213. Wartzok D, Popper AN, Gordon J, Merrill J (2004) Factors affecting the responses of marine mammals to acoustic disturbance. Mar Technol Soc J 37: 6-15.

214. McKenna C (2008) Ocean noise: turn it down. International Fund for Animal Welfare, Yarmouth.

215. Wright AJ, Cosentino AM (2015) JNCC guidelines for minimising the risk of injury and disturbance to marine mammals from seismic surveys: We can do better. Mar Pollut Bull.

216. Goold JC, Coates RFW (2006) Near source, high frequency air-gun signatures. IWC Seismic Workshop.

217. Hermannsen L, Tougaard J, Beedholm K, Nabe-Nielsen J, Madsen PT (2015) Characteristics and Propagation of Airgun Pulses in Shallow Water with Implications for Effects on Small Marine Mammals. PLoS One 10: e0133436.

218. Gould JC, Fish PJ (1998) Broadband spectra of seismic survey air-gun emissions, with reference to dolphin auditory thresholds. Journal of the Acoustical Society of America 103: 2177-2184.

219. Nieukirk SL, Mellinger DK, Moore SE, Klinck K, Dziak RP, et al. (2012) Sounds from airguns and fin whales recorded in the mid-Atlantic Ocean, 1999-2009. J Acoust Soc Am 131: 1102-1112.

220. Nieukirk SL, Stafford KM, Mellinger DK, Dziak RP, Fox CG (2004) Lowfrequency whale and seismic airgun sounds recorded in the mid-Atlantic Ocean. J Acoust Soc Am 115: 1832-1843.

221. Stafford KM, Nieukirk SL and Fox CG (1999) An acoustic link between blue whales in the Eastern Tropical Pacific and the Northeast Pacific. Mar Mamm Sci 15: 1258-1268.

222. Parsons EC, Dolman SJ, Jasny M, Rose NA, Simmonds MP, et al. (2009) A critique of the UK's JNCC seismic survey guidelines for minimising 
acoustic disturbance to marine mammals: best practise? Mar Pollut Bull 58: 643-651.

223. DeRuiter SL, Tyack PL, Lin YT, Newhall AE, Lynch JF, et al. (2006) Modeling acoustic propagation of airgun array pulses recorded on tagged sperm whales (Physeter macrocephalus). J Acoust Soc Am 120: 4100-4114.

224. Wright AJ, Aguilar Soto N, Baldwin AL, Bateson M, Beale C, et al (2007a) Anthropogenic noise as a stressor in animals: a multidisciplinary perspective. International Journal of Comparative Psychology 20: 250-273.

225. Wright AJ, Aguilar Soto N, Baldwin AL, Bateson M, Beale C, et al (2007b) Do marine mammals experience stress related to anthropogenic noise? International Journal of Comparative Psychology 20: 274-316.

226. Bálint, MS, Domisch S, Engelhardt CHM, Haase P, Lehrian S, et al. (2011) Cryptic biodiversity loss linked to global climate change. Nature Climate Change 1: 313-318.

227. Dawson TP, Jackson ST, House JI, Prentice IC, Mace GM (2011) Beyond predictions: biodiversity conservation in a changing climate. Science 332: 53-58.

228. Pauls SU, Nowak C, Bálint M, Pfenninger M (2013) The impact of global climate change on genetic diversity within populations and species. Mol Ecol 22: 925-946.

229. Mendez M, Subramaniam A, Collins T, Minton G, Baldwin R, et al. (2011) Molecular ecology meets remote sensing: environmental drivers to population structure of humpback dolphins in the Western Indian Ocean. Heredity (Edinb) 107: 349-361.

230. Amaral AR, Beheregaray LB, Bilgmann K, Boutov D, Freitas L, et al. (2012) Seascape genetics of a globally distributed, highly mobile marine mammal: the short-beaked common dolphin (genus Delphinus). PLoS One 7: e31482.

231. Gaspari S, Holcer D, Mackelworth P, Fortuna C, Frantzis A, et al. (2013) Population genetic structure of common bottlenose dolphins (Tursiops truncatus) in the Adriatic Sea and contiguous regions: implications for international conservation. Aquatic Conserv: Mar Freshw Ecosyst 25: 212-222.

232. Bouzat JL (2010) Conservation genetics of population bottlenecks: the role of chance, selection, and history. Conservat Genet 11: 463-478.

233. Whitehead A, Anderson SL, Kuivila KM, Roach JL, May B (2003) Genetic variation among interconnected populations of Catostomus occidentalis: implications for distinguishing impacts of contaminants from biogeographical structuring. Mol Ecol 12: 2817-2833.

234. Markert JA, Champlin DM, Gutjahr-Gobell R, Grear JS, Kuhn A, et al (2010) Population genetic diversity and fitness in multiple environments. BMC Evol Biol 10: 205.

235. Frankham R, Ballou JD, Briscoe DA (2010) Introduction to conservation genetics, (2ndedn). Cambridge University Press, Cambridge, UK.

236. Toschi A (1965) Mammalia: Lagomorpha, Rodentia, Carnivora, Artiodactyla, Cetacea. Fauna d'Italia, Vol. 7. Edizioni Calderini, Bologna.

237. Notarbartolo di Sciara G, Bearzi G (2002) Cetacean direct killing and live capture in the Mediterranean Sea. In: G Notarbartolo di Sciara (Ed.), Cetaceans of the Mediterranean and Black Seas: state of knowledge and conservation strategies. A report to the ACCOBAMS Secretariat, section 5.

238. Cabrera A (1925) Los grandes cetàceos del Estrecho de Gibraltar, su pesca y explotaciòn. Trabajos Museo Nacional de Ciencias Natuales, Madrid, Serie Zoologica 52: 5-48.

239. Tønnessen JN abd Johnsen AO (1982) The history of modern whaling. University of California Press, Berkeley and Los Angeles.

240. Sanpera C, Aguilar A (1992) Modern whaling off the Iberian Peninsula during the 20th Century. Report of the International Whaling Commission 42: 723-730.

241. Barone G (1895) Modificazioni delle abitudini del delfino comune (Delphinus delphis) osservate in Liguria e prodotte dal generalizzarsi della pesca intensiva. Neptunia 10: 156-164.
242. Di Natale A (1990) Interaction between marine mammals and Scombridae fishery activities: The Mediterranean case. FAO Fisheries Report 449: 167-174.

243. Cagnolaro L, Notarbartolo di Sciara G (1992) Attività di ricerca sui cetacei e loro status di conservazione in Italia. Boll. Mus. Ist. biol. Univ. Genova 56-57: 53-85.

244. Dawson S, Wade P, Slooten E, Barlow, J (2008) Design and field methods for sighting surveys of cetaceans in coastal and riverine habitats. Mammal Review, 38: 19-49.

245. Mann J, Connor RC, Tyack PL, Whitehead H (2000) Cetacean societies: field studies of dolphins and whales. University of Chicago Press.

246. McGuire TL, Stephens A (2014) Report of a Workshop on Cook Inlet Beluga Whale Biopsy. Prepared for Pacific States Marine Fisheries Commission and National Marine Fisheries Service, Alaska Region, Office of Protected Resources.

247. Gozalbes Aparicio P, Agusti C, Fraija N, Raga JA (2014). Progress Report on the Mediterranean Database of Cetacean Strandings. Contract RAC/ SPA, no 24/2013/RAC/SPA.

248. Perrin WF, Geraci JR (2008). Stranding. In Perrin WF, Würsig B, Thewissen JGM (Eds.), Enciclopedia of Marine Mammals, (2ndedn) Academic Press.

249. IWC (International Whaling Commission) (2014) Report of the Joint IWC-ACCOBAMS Workshop on Reducing Risk of Collisions between Vessels and Cetaceans.

250. Couvat J, Gambaiani D (2013) Evaluation of the technical solutions and management measures implemented at the international level to reduce the risks of collisions between ships and large cetaceans. Souffleurs d'Ecume.

251. Laist DW, Knowlton AR, Pendleton D (2014) Effectiveness of mandatory vessel speed limits for protecting North Atlantic right whales. Endang Species Res 23: 133-47.

252. IWC (International Whaling Commission) (2011) Report of the Joint IWC-ACCOBAMS Workshop on Reducing Risk of Collisions between Vessels and Cetaceans. Paper IWC/63/CC8 presented to the Annual Meeting of the International Whaling Commission.

253. Huntington HP, Daniel R, Hartsig A, Harun K, Heiman M, et al. (2015) Vessels, risks, and rules: Planning for safe shipping in Bering Strait. Mar Policy 51: 119-127.

254. Conn PB, Silber GK (2013) Vessel speed restrictions reduce risk of collision-related mortality for North Atlantic right whales. Ecosphere 4: $1-16$.

255. Nowacek DP, Bröker K, Donovan G, Gailey G, Racca R, et al. (2013) Responsible practices for minimizing and monitoring environmental impacts of marine seismic surveys with an emphasis on marine mammals. Aquat Mamm 39: 356-377.

256. JNCC (U.K. Joint Nature Conservation Committee) (1998) Guidelines for minimising acoustic disturbance to marine mammals from seismic surveys. Joint Nature Conservation Committee, Peterborough, UK.

257. JNCC (UK. Joint Nature Conservation Committee) (2010) JNCC guidelines for minimizing the risk of injury and disturbance to marine mammals from seismic surveys August 2010. Joint Nature Conservation Committee, Aberdeen, UK.

258. Gomez-Salazar C., F. Trujillo, M. Portocarrero-Aya, and H. Whitehead (2012) Population, density estimates, and conservation of river dolphins (Inia and Sotalia) in the Amazon and Orinoco river basins. Marine Mammal Science 28: 124-153.

259. Hooker SK, Whitehead H, Gowans S (1999) Marine Protected Area Design and the Spatial and Temporal Distribution of Cetaceans in a Submarine Canyon. Conservation Biology 13: 592-602.

260. Hooker SK, Gerber LR (2004) Marine Reserves as a Tool for EcosystemBased Management: The Potential Importance of Megafauna Bioscience 54: 27-39.

261. Gormley AM, Slooten E, Dawson S, Barker RJ, Rayment W, et al. (2012) First evidence that marine protected areas can work for marine mammals. J Appl Ecol 49: 474-480. 
Citation: Pace DS, Tizzi R, Mussi B (2015) Cetaceans Value and Conservation in the Mediterranean Sea. J Biodivers Endanger Species S1:

Page 24 of 24

262. Hoyt E (2005) Marine Protected Areas for Whales, Dolphins and Porpoises: A world handbook for cetacean habitat conservation. Earthscan, London and Washington, DC.

263. Hoyt E (2012) Summary Proceedings of the Second International Conference on Marine Mammal Protected Areas (ICMMPA 2)

264. Panigada S, Zanardelli M, MacKenzie M, Donovan C, Melin F, Hammond PS (2008) Modelling habitat preferences for fin whales and striped dolphins in the Pelagos Sanctuary (Western Mediterranean Sea) with physiographic and remote sensing variables. Remote Sensing of Environment 112: 3400-3412.

265. Hoyt E (2015) Summary Proceedings of the Third International Conference on Marine Mammal Protected Areas (ICMMPA 3).

266. Corrigan CM, Ardron JA, Comeros-Raynal MT, Hoyt E, Notarbartolo di Sciara G, Carpenter KE (2014) Developing important marine mammal area criteria: learning from ecologically or biologically significant areas and key biodiversity areas. Aquat Conserv: Mar Freshw Ecosyst 24: 166-183.

267. Game ET, Grantham HS, Hobday AJ, Pressey RL, Lombard AT, et al. (2009) Pelagic protected areas: the missing dimension in ocean conservation. Trends Ecol Evol 24: 360-369.

268. Hobday AJ, Maxwell SM, Forgie J, McDonald J, et al. (2014) Dynamic ocean management: integrating scientific and technological capacity with law, policy and management. Stanford Environ Law J 33: 125-165.

269. Wearing SL, Cunningham PA, Schweinsberg S, Jobberns C (2014) Whale Watching as Ecotourism: How Sustainable is it? Cosmopolitan Civil Soc J 6: 38-55.

270. Lien J (2001) The Conservation Basis for the Regulation of Whale Watching in Canada by the Department of Fisheries and Oceans: A Precautionary Approach, Canadian Technical Report of Fisheries and Aquatic Sciences, No. 2363.

271. Hoyt E (2001) Whale Watching 2001; Worldwide tourism numbers, expenditures, and expanding socioeconomic benefits. A special report from the International Fund for Animal Welfare.
272. Cisneros-Montemayor A, Sumaila U (2010) A global estimate of benefits from ecosystem-based marine recreation: potential impacts and implications for management. J Bioeconom 12: 245-268.

273. Pew Environment Group (2012) Ocean Earth: How Rio+20 can and must turn the tide. The Pew Environmental Group, Policy Recommendations, Washington DC.

274. Kaschner K, Pauly D, Trites AW, Watson R (2006) Mapping world-wide distributions of marine mammal species using a relative environmental suitability (RES) model. Mar Ecol Prog Ser 316: 285-310.

275. Scarpaci C, Parsons ECM (2011) Recent Advances in Whale-Watching Research: 2010-2011. Tourism in Marine Environments 8: 161-171.

276. Pirotta E, Laesser BE, Hardaker A, Riddoch N, Marcoux M, et al. (2013) Dredging displaces bottlenose dolphins from an urbanised foraging patch. Mar Pollut Bull 74: 396-402.

277. Pirotta E, Milor R, Quick N, Moretti D, Di Marzio N, et al. (2012) Vessel noise affects beaked whale behavior: results of a dedicated acoustic response study. PLoS One 7: e42535.

278. Blewitt M (2008) Dolphin-human interaction interactions in Australian waters. Australian Zoologist 34: 197-210.

279. Parsons ECM (2012a) The negative impact of whale watching. J Mar Biol 2012: 1-9.

280. IWC (International Whaling Commission) (2012) A review of whale watch guidelines and regulations around the world. Document WWREGS 2013.

281. IWC (International Whaling Commission) (2009) Report of the IWC Scientific Committee. J Cet Res Manage 11: 1-74.

282. Katz E (1992) The call of the wild. Envir Ethics 14: 265-273.
This article was originally published in a special issue, entitled: "Usefulness of Biodiversity to Humans", Edited by Giulia Guerriero and Daniela Silvia Pace 